\title{
International environmental agreements (IEAs): An integrated perspective on the concept of effectiveness
}

\author{
Chenaz B. Seelarbokus \\ Department of Political Science and International Affairs, Kennesaw State University, Kennesaw, United States of America \\ Email address: \\ cseelarb@kennesaw.edu
}

To cite this article:

Chenaz B. Seelarbokus. International Environmental Agreements (IEAs): An Integrated Perspective on the Concept of Effectiveness. International Journal of Environmental Protection and Policy. Vol. 2, No. 2, 2014, pp. 76-95. doi: 10.11648/j.ijepp.20140202.15

\begin{abstract}
The effectiveness of international environmental agreements (IEAs) has been conceptualized in various ways in the literature, and several assessment methodologies have been postulated. There has not been any attempt at integrating the various perspectives, nor of determining the fit between the assessment methodology and the goals of the IEAs or of the IEA institutions. This article reviews the various effectiveness conceptualizations, and proposes the 'effectiveness web' as an integrative framework for understanding the inter-relationships that exist among the various determinants and potential indicators of IEA effectiveness. This article argues for an evolutionary and dynamic conceptualization of IEA effectiveness, as well as a multi-track assessment of effectiveness, which is more in line with the activities of the IEA institutions. This article identifies potential indicators for various stages of the life-cycle of an IEA, and using the premise of global environmental sustainability as guiding framework, provides a hierarchy of effectiveness assessment methodologies.
\end{abstract}

Keywords: Effectiveness, Environmental Regimes, Environmental Treaties, International Environmental Agreements, International Environmental Cooperation, Assessment

\section{Introduction}

Since the 1972 United Nations Conference on the Human Environment, the heightened imperative for global environmental protection has resulted in a sustained growth in the adoption of international environmental agreements (IEAs). We now have many important IEAs on various issue areas such as desertification, biodiversity protection, climate change, ozone layer depletion, acid rain, protection of endangered and migratory species, protection of fisheries and marine waters, transport of hazardous wastes, and wetland protection, inter alia. With all these IEAs in existence, some for several decades, it is logical to assume that global environmental conditions have improved. To what extent have the IEAs improved the environmental problems that gave rise to them? How effective indeed have the IEAs been in improving the global environment?

Unfortunately, it is not easy to answer the above questions. While numerous studies have focused on the effectiveness of IEAs [e.g. 1, 2-14], no clear correlation has been established between the operation of the IEAs and the state of the environment. Despite the tremendous growth in IEAs, we still do not know much about the effect of these IEAs on the global environment. One major problem in establishing the link between IEA operation and the state of the environment is that most of the studies on IEA effectiveness have been conducted within the purview of regime theory, whereby effectiveness is related with a change in the behavior of the relevant actors [e.g. 3, 5, 6-8, 15-20].

There has been a purposeful and systematic repudiation of environmental considerations in IEA effectiveness studies mostly due to the general perception among regime scholars that assessing environmental conditions is not the "most methodologically manageable" means of determining IEA effectiveness [18 p. 179]. Difficulties of the environmental problem-solving perspective are associated with the complexities of measuring the environmental impacts of environmental regimes or of obtaining reliable and consistent data [7 p. 200,18 p. $179,21,22$ p.13], the long time lag between entry into force of IEAs and observable impacts [9, 20, 23 p. 6, 24 p. 142], and man's incomplete understanding of the environmental problems (e.g. climate change) [25], inter alia. Researchers also often reminisce about the difficulties associated with such confounding factors as natural variability and weather fluctuations $[26 \mathrm{p}$. $176]$, and the problems associated with diffuse sources of pollution or multiple causes of environmental degradation [24 p. 142, 27 p.103]. 
The evoking of the above-mentioned difficulties implicitly posits the behavioral approach as the most feasible or most appropriate means of assessing IEA effectiveness. Yet, the behavioral approach is not necessarily less complicated than an environmental problem-solving perspective. Even those who favor the behavioral approach recognize that there are serious challenges posed by the behavioral methodology. As noted by Skjaerseth and Wettestad[28], "[r] ecording behavioral change caused by the regime or institution in question is full of spurious fallacies since such change can be caused by factors unrelated to the policy in question, like economic fluctuations and technological innovation" (p. 106). Though Skjaerseth and Wettestad[28] consider that establishing causal links through environmental assessments is a "more uncertain process" because "natural variability makes it difficult to identify human-induced changes over time," (p. 106) the fact remains that no true comparison can be made as these behavioral analyses do not cite any studies which empirically demonstrate the purported difficulties in interpreting findings due to natural variability.

In fact, scientists routinely differentiate between human-induced environmental changes and natural variations in their determination of environmental quality, environmental impacts, or trends in environmental parameters [e.g. 29, 30-37], and there has been a growing emphasis in linking environmental systems with human systems in environmental management [e.g.38]. As will be discussed later, the work program and decisions of the IEA institutions (e.g. Secretariats, Conference of Parties (COPs,) Councils, Scientific Committees, etc.) show that lots of resources and efforts are devoted to environmental assessments or the development of environmental indicators, as well as strategies for ensuring the reliability and accuracy of data [e.g. 35, 39-42].

Moreover, the behavioral approach, especially through its methodology of counterfactual analysis and process tracing, is no "panacea" as well since the demonstration of causal mechanisms through process tracing "can require enormous amounts of information," and "is weakened when data is not accessible on key steps in a hypothesized process" [43]. It is difficult to determine the extent to which "regime norms or rules modify or perhaps merely reflect the perspectives and actual behavior of governments, let alone their subjects" [18 p. 167]. According to Victor et. al. [44 p. 6], any such relationship may merely be "partial or indirect," with even the possibility of some of the behavioral changes engendered by the treaties running counter to the ultimate goals of the treaties [e.g. 45 p.16].

A further complication occurs in that environmental actors are many, operating both at the international level and within the domestic hierarchy. Further, actors do have multiple interactions with each other, and these interactions may influence behavior as well. For a global IEA such as the Convention on Biological Diversity (CBD), for example, which has 193 party members, it can be an equally complex undertaking, if not more so, to assess and then correlate the behavioral change of these numerous actors to the operation of the IEA, as it is to analyze the environmental modification stimulated by the IEA. Skjaerseth[28 p. 107] rightly notes that it is a "daunting challenge" and a "tall order" to try and "[a]ggregat[e] information and national assessments into overall scores and overriding explanations." Thus, focusing on behavioral analysis may therefore not be less "shadowy" or less a "moving target" [46 p. 277] than the widely disregarded problem-solving perspective, and in certain cases, it may not even "mean a great deal" [18 p. 173]. It is also not clear that the "long time lags" disqualifier attributed to the environmental problem-solving methodology does not also apply to the behavioral perspective. Changes in the behavior of relevant actors do not occur overnight. Typically, implementation of IEAs involves enactment of legislation, formulation of new rules and procedures, and new enforcement actions. In a democratic governance system, these processes involve lengthy debates in the legislative systems, the holding of public hearings, and the formulation of new policies, all of which occur according to specific time schedules and procedures. Thus, the time from treaty ratification to observable behavioral change in the relevant actors can be a lengthy process as well. The behavioral approach has also been criticized in view of its "general bias in the direction of assuming that problems need to be relatively "simple" or "well-structured"' [47], a fact which overlooks the realities of international environmental negotiations and the nature and complexity of global environmental problems.

So, which methodology is to be recommended for analyzing IEA effectiveness? And on a practical level, which methodology would be most useful for informing international environmental policy-making? Answering these questions would necessitate matching the methodology with the goals of the institutions responsible for managing the IEAs. An examination of the IEA institutions reveals that the current landscape of IEA effectiveness studies is dotted with several conceptualizations, methodologies and conclusions. Research into the Mediterranean Action Plan (MAP), for example, has shown that different key stakeholders dealing with the regime tend to view effectiveness differently [12]. Similarly, an analysis of reports of the COPs or of other publications of the IEA Secretariats (e.g. the Convention on Migratory Species (CMS), the Convention on Long-Range Transboundary Air Pollution (LRTAP), the Basel Convention on the Control of Transboundary Movements of Hazardous Wastes and their Disposal, or the Convention on Wetlands of International Importance especially as Waterfowl Habitat (Ramsar Convention)) shows that the COPs normally focus on a multi-track perspective of effectiveness, with a growing emphasis however on the need for establishing trends in environmental and ecological indicators. Thus, the IEA institutions often view effectiveness in terms of the effective implementation of specific key provisions of the IEAs, and includes variables such as increasing participation in the IEAs, promoting technical and scientific cooperation to assist domestic implementation, facilitating domestic enactment of 
appropriate legislation, as well as the enunciation and monitoring of key environmental indicators of direct relevance to the operation of the IEAs [e.g. 48, 49 pp. 1-3, 50-56].

From a practical standpoint, therefore, it seems that there is no one fixed way of conceptualizing or assessing IEA effectiveness. How can we make sense of the various perspectives on IEA effectiveness? Under what circumstances is one methodology more appropriate than another? Can we integrate the various understandings of IEA effectiveness into one coherent template, whereby the interactions and inter-relationships among the various determinants and indicators of IEA effectiveness are clear? How can we conceptualize and assess IEA effectiveness such that the results have practical significance to policy-makers and IEA institutions, rather than being merely theoretical or conjectural?

This article addresses the above questions by providing an integrative framework, through the concept of the "effectiveness web," for the various conceptualizations of effectiveness. This article shifts the conceptualization of IEA effectiveness from static understandings to a new visualization of effectiveness as an evolutionary process. Effectiveness can be viewed along a continuum, in tandem with the life-cycle of the IEA. As the IEAs and the associated institutional mechanisms evolve and mature, different means of assessing IEA effectiveness can be entertained. The evolutionary understanding of effectiveness allows for the identification of core and peripheral determinants of effectiveness as well as interim and long-term indicators of effectiveness. Moreover, the effectiveness web identifies a missing link in the behavioral studies, which may be one of the reasons why we do not have sufficient information on the environmental effectiveness of IEAs. This missing link is the association between the behavioral change and the environmental state at the domestic and international levels.

Using global environmental sustainability as guiding framework, this article also examines the fit between various IEA effectiveness assessment methodologies and the nature and operation of IEAs, as well as the goals of the IEA institutions - a theme which rarely emerges in the literature on IEA effectiveness. This article considers that any attempt at evaluating the effectiveness of IEAs has to be grounded in the relevance of the methodology to practical policy-making and to the demands of the IEA institutions. Since IEAs do not all have the same goals and objectives, and each has a different life-span and membership profile, it is obvious that the methodology adopted will have to take into account the nature of the issue area, the age of the treaty, the resources available for the evaluation, as well as the purposes meant to be served by the evaluation. Thus, a hierarchy of assessment methodologies can be established based on the limiting factors for the evaluation, as well as the relevance of the assessments to global environmental policy-making.

This article is structured as follows. In the first section, the various definitions and conceptualizations of IEA effectiveness are presented. The second section presents the effectiveness web as a means of synthesizing the existing knowledge in an integrated framework of the various determinants and possible indicators of IEA effectiveness. Finally, a hierarchy of assessment methodologies is presented.

\section{Conceptualizations of IEA Effectiveness}

The term 'effectiveness' does not seem to lend itself to a straightforward interpretation. It has been described as an "elusive concept" [20 p. 3, 57 p. 274], meaning "distinctly different things to different communities" [58]. Various researchers have provided different analytical approaches and understandings of the term. Vogler [18 pp. 155-178] provides four different angles of viewing effectiveness: (i) effectiveness as international law, whereby effectiveness is measured in terms of the legal status of rules and the extent to which states consider themselves bound by them; (ii) effectiveness as transfer of authority from a national to an international level; (iii) effectiveness as behavior modification, where the behavioral change of actors is analyzed pursuant to the establishment of the regimes; and (iv) effectiveness as problem-solving, where the effects of the regime on "sustainability and equitable management of the commons" are considered. Young and Levy's [20] five-pronged approach to the concept of effectiveness supplements Vogler's understanding with the addition of the following: (i) the economic approach, which adds the element of efficiency criteria to the legal definition; and (ii) the normative approach, which includes considerations of "fairness or justice, stewardship, participation," among others (p. 3). Honkonen adds the following additional dimensions: (i) political effectiveness, which is equated with participation in the regime; (ii) administrative and institutional effectiveness, which refers to the "general procedural and institutional flexibility of the regime" ( $p$. 289); and (iii) local effectiveness, which looks at the impact (or harm) of the regime on local communities in the developing world (pp. 288-291).

Apart from the above multilayered focus on effectiveness, Kaczorowska [59] proposes an impact-related perspective, analyzing the effectiveness of trade conventions by determining whether they "produce the desired effect." Peterson [60] provides a dichotomy between 'compliance effectiveness' and 'result effectiveness,' where 'compliance effectiveness' relates to the respect of regime prescriptions and 'result effectiveness' relates to "real environmental improvement" (p. 115). Helm and Sprinz [9] have attempted to directly use the problem-solving approach to analyze IEA effectiveness, relying on the construction of an effectiveness score based on a "no-regime counterfactual" and a "collective optimum" [see also 61, 62]. Miles et al. [63] have subsequently used this approach of no-regime counterfactual and collective optimum in their analysis of fourteen IEAs. 
Overall, however, as mentioned in the introductory paragraphs, the literature has strongly favored the behavioral modification perspective on IEA effectiveness. Indeed, it seems that the "object of the agreement is to affect state behavior" [5]. Skjaerseth's [64] analysis of the Oslo Convention involves an analysis of the behavioral change of state actors (e.g. UK, Portugal, Switzerland, inter alia) leading to the establishment of national licensing systems ( $p$. 82). Likewise, cases studied in Miles et. al. [63] focus on national legislation, national policies, national implementation strategies, and the development of comprehensive action plans.

Recently, however, there has been growing emphasis on the need to link the concept of effectiveness to environmental improvements. Kutting's concept of "environmental effectiveness" considers the "degree to which the degrading or polluting processes and consequences are arrested or reversed" [58 p.36]. However, in her application of the concept of environmental effectiveness to her two case studies, viz. the LRTAP and the MAP, Kutting focuses on four effectiveness determinants namely, economic structures, time, science, and regulatory structures - and not on environmental conditions per se. Seelarbokus's[65] concept of "effectiveness as environmental modification" relies on the establishment of trends in environmental indicators directly abstracted from within the IEA texts. The IEA Database project [66] also lists environmental performance indicators of direct relevance to IEAs - a clear indication of the growing recognition of the need to link IEA operation with the state of the environment. Young's [67] recent review of the current state of knowledge on IEA effectiveness provides a snapshot of various implications of IEA effectiveness studies. However, the review approaches effectiveness solely from the institutional bias that currently permeates the literature on IEA effectiveness, and disconcertingly disregards efforts undertaken by the IEA institutions and independent researchers to determine the environmental effectiveness of the IEAs.

In order to provide a holistic outlook on IEA effectiveness, and to facilitate an integrated understanding of the various determinants and potential indicators of IEA effectiveness, I propose the concept of the "effectiveness web." Since potential determinants of IEA effectiveness may include any variable influencing the IEA right from its birth up to implementation phase, I adopt an evolutionary understanding of effectiveness, and attempt to capture this broad understanding through the comprehensive template of the effectiveness web. Importantly, the effectiveness web takes into account the programmatic activities and projects of IEA institutions as well as their conceptualizations of effectiveness. Most of the current discussions on IEA effectiveness disregard the undertakings of the IEA institutions. In their recommendation for a "stakeholder process" to determine collective optima, for example, Hovi et al [14] do not mention the IEA institutions as an important stakeholder. Yet, they are the major stakeholders in IEA management, and the ones that are most directly involved in the analysis of IEA effectiveness. Details on the effectiveness web are provided below.

\section{The Effectiveness Web}

The effectiveness web emphasizes the fact that analyzing the effectiveness of IEAs is a process - rather than a single static undertaking. Being a direct outcome of international negotiations, an IEA (and its effectiveness) can be framed first and foremost within the context of politics (domestic and international), the processes of international negotiations, and the design and structure of the legal texts of the IEAs. Existing research has shown that different issue areas command different levels of scientific consensus, different public perceptions of the problem, and different levels of international environmental cooperation [e.g. 9, 16, 68-73]. Thus, IEA effectiveness can be deemed to depend on the nature of the issue area and the science governing the issue area - what has been termed as the "malignity" of the problem [9] or "problem malignancy" [13 p. 583, 63].

The success of international negotiations has been shown to depend, inter alia, on the traits of negotiators, bargaining, resolution of the typical North-South conflict, and the role that non-state actors (e.g. NGOs) play in agenda-setting and in the processes of treaty-making [16, 68, 72-93]. Thus, it is likely that these factors will also influence the design and structure of the IEA finally agreed upon. IEA design, on its part, has been deemed as an explanatory variable for regime effectiveness - especially provisions relating to implementation review mechanisms (IRMs), reporting and verification procedures, and non-compliance procedures [e.g. 3, 5, 94-98].

Once formed, the IEA needs to be adopted internationally and then implemented domestically. It can thus be surmised that the effectiveness of an IEA also depends on the level of participation (that is, state ratification of the IEA) secured by the IEA and the degree of its domestic implementation. From within the economics field, especially game theory, studies have focused on the influence of domestic state characteristics on patterns of treaty ratification [99-101], and on the influence of incentive instruments such as side payments, taxes, trade sanctions, and globally tradable emission permits [e.g. 102, 103-115]. Domestic implementation, on its part, has been related to the structure and stability of political structures, as well as the socioeconomic and institutional capacities of the countries [e.g. $2,116,117,118,119$ pp. 42-63, 120-123, 124 p. 89, 125, 126, 127 pp. 13-28, 128, 129].

As is obvious from the above, IEA effectiveness can be influenced by numerous variables. What is the level of influence of the above parameters on ultimate IEA effectiveness? From our holistic and evolutionary approach, the realm of IEA effectiveness can be considered to comprise of different strata which mutually influence each other. Abstracting from our current understanding of effectiveness, the core determinants of IEA effectiveness can 
be considered to be: (i) the dynamics of international environmental negotiations and the processes of IEA formation; (ii) the characteristics of the legal text adopted by the international community; (iii) the level of participation in the IEA; and (iv) the capacity or will for implementation at the domestic level. The varying influences of the determinants of IEA effectiveness can be depicted by a series of overlapping concentric circles, as shown in Figure 1 , with the inner circles deemed to be exerting a greater leverage on IEA effectiveness. Domestic implementation is placed at the core of IEA effectiveness since no IEA can be deemed successful if it is not implemented domestically by the party members.

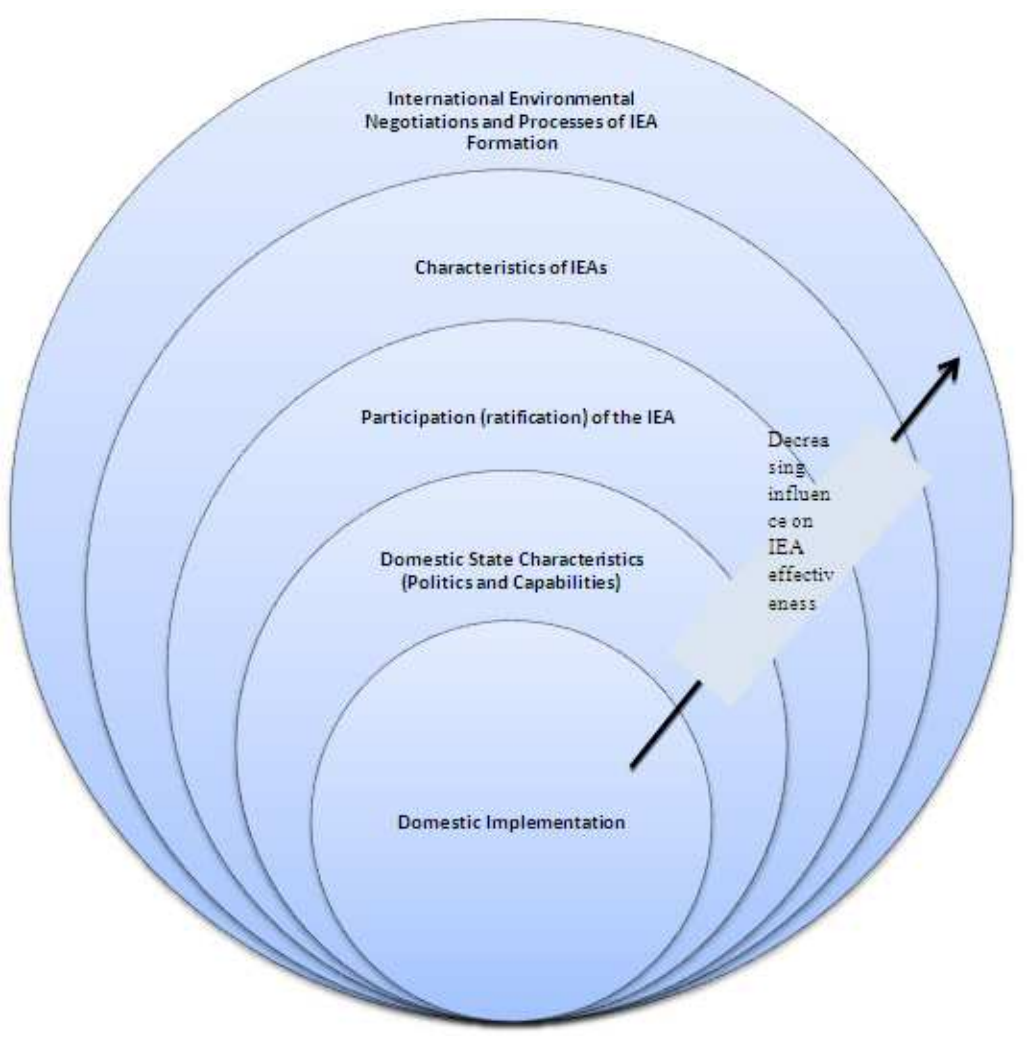

Figure 1. Strata of factors influencing the effectiveness of IEAS.

These parameters, however, are always in dynamic interactions, effectively establishing a web of relationships and mutual influences. In analogy with the food web and its trophic levels, the "effectiveness web" can be considered to comprise of core "determining levels," where a determining level is understood to constitute a major determinant of IEA effectiveness. The three main determining levels of the effectiveness web can be considered to comprise: (i) international negotiations (and hence, IEA formation and design); (ii) participation in IEAs; and (iii) domestic implementation of the IEAs. To note that IEA design is collapsed into international negotiations as the structure of the adopted IEA text is a direct outcome of the processes of international negotiations.

The higher we move along the effectiveness web, the greater the influence of the determining level on IEA effectiveness, and the greater its vulnerability to the lower determining levels. International negotiations and the processes of IEA formation perform as a primary determining level as they directly influence the internal structure and design of IEAs and determine the level of participation in them. How well a particular IEA has been structured will ultimately determine the participation level and the strategies implemented to fulfill its legal requirements, as discussed earlier. Thus, the processes of international negotiations and the resulting design of the IEA are a primary force and the foundational bedrock in determining whether or not we have an effective legal instrument for solving an international environmental problem.

Ensuring near global participation in IEAs (the secondary determining level) is a necessary step towards securing widespread international environmental cooperation, and many of the treaty texts and/or IEA institutions do seem to consider enlisting maximum participation as a crucial stepping-stone towards greater IEA effectiveness [130]. ${ }^{1}$ As Susskind notes, if "too few countries ratify an agreement, the cumulative efforts of those living up to their promises may be insufficient to reverse the problem" [131 p. 14]. Participation, as discussed earlier, is influenced by the structure and provisions of the IEAs, the socio-economic capabilities of countries to ratify the IEAs, the level of civil society engagement in environmental issues, the influence

\footnotetext{
${ }^{1}$ Also, see the first paragraph of the Paris Protocol to the Ramsar Convention, available at http://www.ramsar.org/key_paris_protocol.htm.
} 
of NGOs, and the nature of the issue area, among others. Despite arguments to the effect that participation is not useful as an indicator of effectiveness as participating countries may not be committed to fully implement the provisions of the IEAs [e.g. 18 p. 156, 132 p. 200], participation nevertheless takes on the role of being an important precursor to effective international environmental cooperation, and an indication of the effectiveness potential of IEAs [133]. Domestic implementation, presented as the core level in the strata of effectiveness (Figure 1), functions as a tertiary determining level, thereby reflecting its greater and more direct influence on effectiveness, as well as its vulnerability to the other two determining levels.

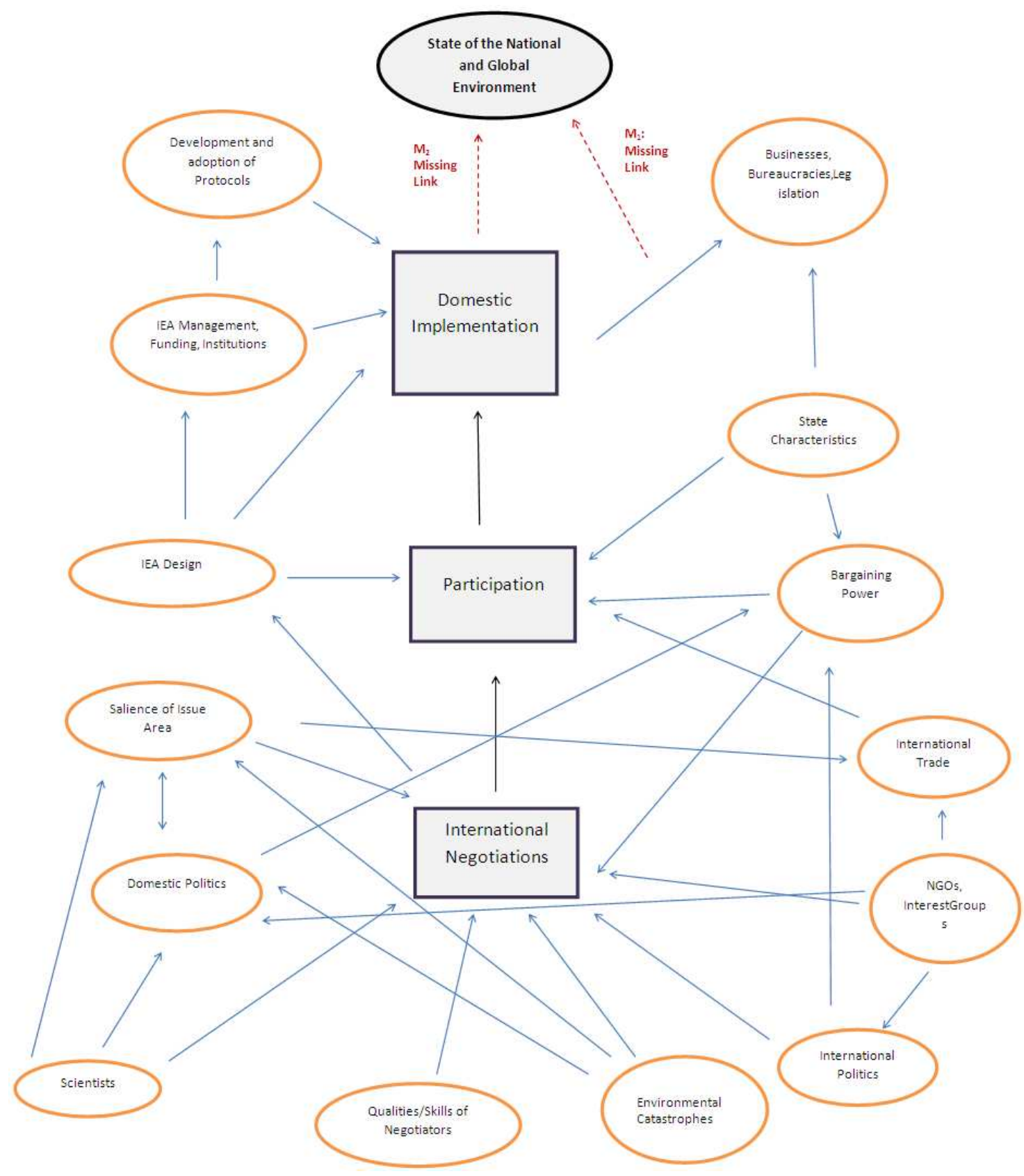

Figure 2. The Effectiveness Web. Core determinants are in square boxes. Peripheral determinants are presented in the circles.

The complexity of the effectiveness web arises mostly due to the fact that each of the determining levels can be influenced by numerous factors. The various elements of the web capture the dynamic aspects of international environmental cooperation and the direct and indirect influences of various parameters on IEA effectiveness (shown by the arrows in Figure 2). Viewed through the framework of the effectiveness web, it is possible to not only have a holistic understanding of IEA effectiveness, but also to have an integrated perspective on the various determinants of IEA effectiveness. As is obvious from Figure 2, IEA effectiveness can be impacted by any of the determining levels or any of the various other influencing variables. In fact, we can think of the determinants of IEA 
effectiveness in terms of core determinants and peripheral determinants (see Table 1).

Table 1. Determinants of IEA effectiveness.

\begin{tabular}{|c|c|}
\hline Core Determinants & Peripheral Determinants \\
\hline $\begin{array}{l}\text { International } \\
\text { Negotiations }\end{array}$ & $\begin{array}{l}\text { - } \\
\text { - } \quad \text { Trade implications } \\
\text { - } \quad \text { Skills of negotiators } \\
\text { - } \quad \text { Sole of non-state actors (e.g. NGOs) } \\
\text { level (including the catalyzing influence } \\
\text { of environmental catastrophes, oil spills, } \\
\text { nuclear accidents, industrial accidents, } \\
\text { etc.) } \\
\text { Domestic and international politics - } \\
\text { (including domestic conditions - e.g. } \\
\text { level of human and economic } \\
\text { development) } \\
\text { Baroaining nower of states }\end{array}$ \\
\hline Participation & $\begin{array}{l}\text { Bargaining power of states } \\
\text { IEA characteristics (e.g. flexibility, } \\
\text { provisions for technology transfer or } \\
\text { financial assistance, transparency, other } \\
\text { participation incentives such as } \\
\text { increasing legitimacy, reputation } \\
\text { benefits, etc.) } \\
\text { State characteristics (e.g. democracy, } \\
\text { political stability, domestic civic } \\
\text { environmentalism, level of economic and } \\
\text { human development, role played in the } \\
\text { international negotiations leading to the } \\
\text { IEA, etc.) } \\
\text { Nature and salience of issue area in } \\
\text { domestic politics } \\
\text { Role of environmental pressure groups } \\
\text { (e.g. NGOs) }\end{array}$ \\
\hline $\begin{array}{l}\text { Domestic } \\
\text { Implementation }\end{array}$ & $\begin{array}{l}\text { Trade implications of IEA } \\
\text { Capacity of states to implement IEA } \\
\text { provisions (e.g. level of economic and } \\
\text { human development, political stability, } \\
\text { strength and effectiveness of domestic } \\
\text { institutions) } \\
\text { Role of environmental NGOs and } \\
\text { lobbying groups } \\
\text { Level of civic environmentalism } \\
\text { Political leadership and commitment to } \\
\text { the environmental goals embodied in the } \\
\text { IEA text } \\
\text { Incentives for implementation (e.g. } \\
\text { technology transfer, financial transfers, } \\
\text { scientific collaboration, etc.) }\end{array}$ \\
\hline
\end{tabular}

The effectiveness web is also useful in bringing together the various research templates dominating the field of environmental regimes (e.g. general international relations, game theory, regime theory, comparative studies on domestic implementation, study of institutions, etc.), and in showing the inter-relationships that can be built upon to provide a more integrated and holistic understanding of IEA effectiveness. Moreover, the effectiveness web allows us to identify 'missing links' between the methodologies or research agendas and the ultimate goal of global environmental protection and sustainability. Indeed, clearly missing in the literature on IEA effectiveness are systematic and comprehensive studies which relate domestic implementation of IEAs to the state of the global environment. Thus, while most of current studies on regime effectiveness have focused on actors' behavioral change, the link between the changed behavior and the state of the environment has not been established (see arrows $\mathrm{M}_{1}$ and $\mathrm{M}_{2}$ in Figure 2). What are the policy implications of these missing links? These are discussed below.

\section{The Missing Link in the IEA Effectiveness Web}

From a global perspective, IEAs perform as an international policy instrument to enhance environmental cooperation by providing institutional and regulatory mechanisms to improve the state of the global environment. This implies that once international consensus has been secured and an IEA has entered into force, the general expectation is that party members will be implementing policies domestically in line with the stipulations of the IEAs. Hence, it is expected that the IEA will be instrumental in bringing about an improvement of first, domestic environmental quality (which also includes the protection of natural habitats and species) and, ultimately, global environmental quality. The link between the state of the environment and an IEA is therefore mutually constitutive: a degraded environment gives rise to an IEA, and an IEA is expected to lead to an improved global environment (see Figure 3).

From an environmental policy standpoint, the availability of environmental data is crucial for strategies meant to strengthen environmental sustainability, promote environmental security, advance environmental justice and equity (both intra- and inter-generational), and secure human rights protection, inter alia $[134$ p.187, 135 p. 227, 136-142, 143 p. 12,144 p. 342,145 p. 2,146 p. 31,147 p. 607,148$]$. Environmental data are also crucial for determining the assimilative and carrying capacity of the environment. Reliable data on the "stock of natural environmental assets" [149 p. 23] have implications for debates on "weak" or "strong sustainability," whereby policy-makers have to decide between development paths which utilize natural resources and other management strategies which are geared towards the conservation or preservation of "every single natural resource" [134 p. 185, 150]. For example, Malone [151] notes that "[e]ffective and sustainable use of the marine environment and its living resources depends on the capability to repeatedly assess and anticipate changes in the status of coastal ecosystems and living resources on national to global scales" (p. 295).

Concern with sustainable development and the consequent need to assess and monitor the state of the environment prompted the 1991 core set of environment indicators of the Organization for Economic Co-operation and Development (OECD) and the subsequent development of the Pressure-State-Response framework [152-155]. The 1992 United Nations Conference on Environment and Development (UNCED) brought a new impetus for 
strengthening the systematic collection of environmental data.

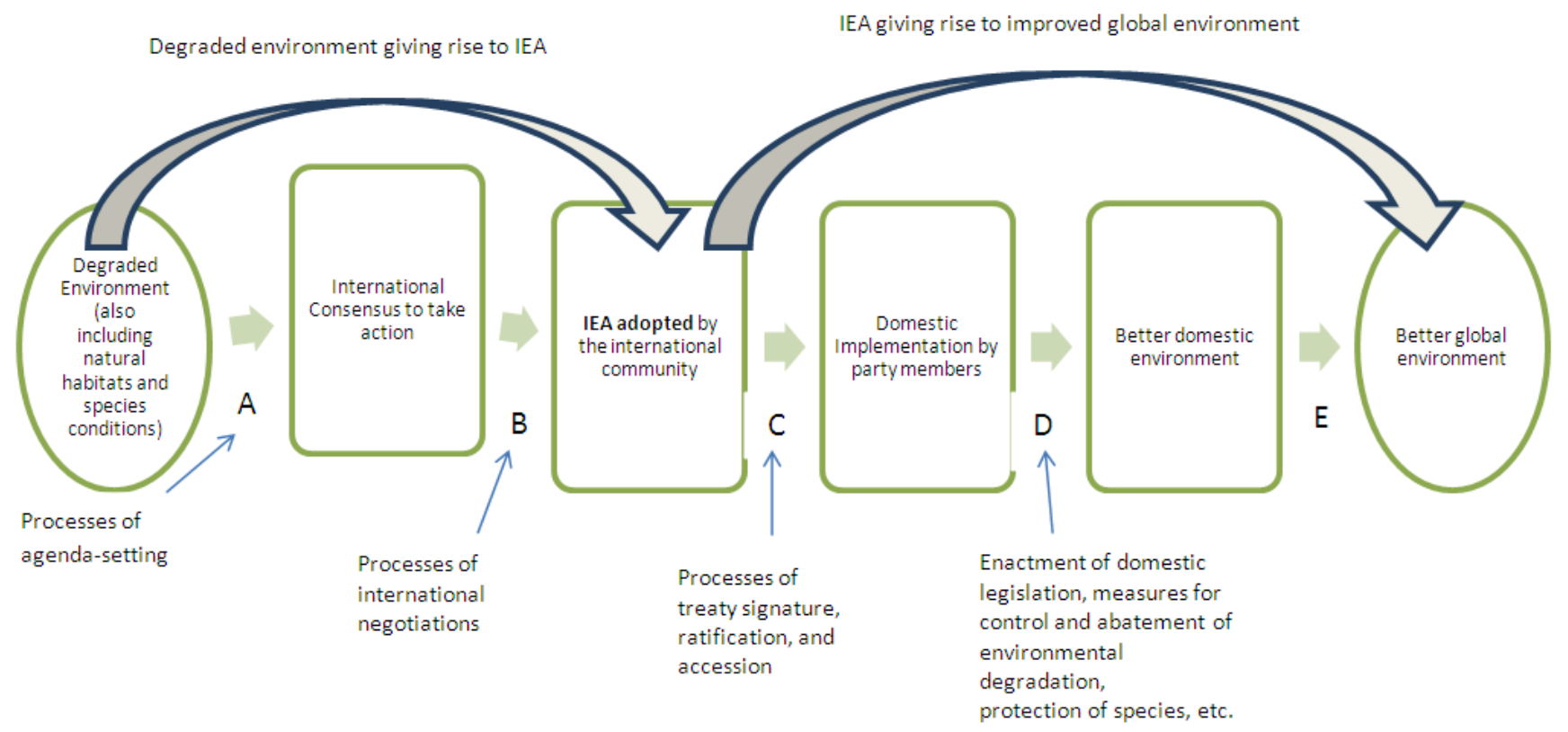

Figure 3. Link between the environment and an IEA.

UNCED's Agenda 21 makes provisions for systems of 'integrated environmental and economic accounting" (IEEA), which presupposes the utilization of sustainable development indicators in national planning and decision-making procedures. This in turn necessitates improved environmental data collection, storing, organization, and assessment. ${ }^{2}$ Since UNCED, several publications have emphasized the need for and the policy-relevance of environmental indicators - e.g. Hammond [156], Pearce et al. [157], and the World Bank's 1995 Monitoring Environmental Progress, among others. Hammond notes that environmental indicators can "capture complex environmental data in an easy-to-communicate form that can heighten public awareness and inspire policy action" (p.9).

The Millennium Ecosystem Assessment as well as the Future We Want, the "outcome document" ${ }^{3}$ of the 2012 Summit on Sustainable Development, both recognize the need for scientific assessments, emphasizing the need for developing indicators, securing key environmental data to engender global environmental sustainability, and the importance of linking science and policy (e.g. the establishment of the Intergovernmental Science-Policy Platform on Biodiversity and Ecosystem Services). The Fifth Global Environmental Outlook (GEO-5) of the United Nations Environment Programme (UNEP) was also launched during the 2012 Summit. In December 2012, UNEP, the World Bank, the OECD, and the Global Green

\footnotetext{
${ }^{2}$ See Chapter 8 "Integrating Environment and Development in Decision-Making" of Agenda 21.www.unep.org/Documents/Default.asp?DocumentID=52\&ArticleID=56 .

${ }^{3}$ The Future We Want. http://www.un.org/en/sustainablefuture/
}

Growth Institute (GGGI) organized an international conference Measuring the Future We Want: An International Conference on Indicators for Inclusive Green Economy/Green Growth Policies, which was aimed at developing indicators for a green economy. UNEP, in partnership with the Fujian Normal University, held another symposium on environmental competitiveness indicators in Fuzhou, China in March 2013.

Environmental data form an integral component of IEA management and evolution. As science progresses, IEAs are amended to incorporate the new reality - e.g. the various LRTAP protocols; the evolution of the 1931 Convention for the Regulation of Whaling into its 1946 version [for details see 158 pp. 15, 16]; the various CMS protocols (e.g. on the European bats, seals in the Wadden Sea, gorillas and their habitats, albatrosses and petrels, etc.), and the CMS Memoranda of Understanding (MoUs) (e.g. on the Siberian crane, slender-billed curlew, Bukhara deer, aquatic warbler, etc.), inter alia. Moreover, considering the fact that some environmental problems exhibit "tipping point" mechanisms [159 p. 12] or "irreversibility effects" [134 p. 185] which often cannot be negated beyond some "critical zones," [160 p. 90] there is a greater imperative to establish immediate and continuous baseline data collection processes.

Indeed, many IEA institutions emphasize the need to obtain scientific data on the environment, and many of the IEA-related programs rely on environmental data for their successful operation - e.g. the Helsinki Commission's (HELCOM) Baltic Sea Action Plan (BASP) [161], and UNEP's Regional Seas Programme, which is focused on linking assessment of the quality of the marine environment with management activities for the development and protection of the marine environment from an 
ecosystem-based approach [e.g. see 162, 163]. Many IEAs or their institutions also have as objectives or vision the ability to accomplish real environmental improvements. MAP's vision is described in the following words:

"A healthy Mediterranean with marine and coastal ecosystems that are productive and biologically diverse for the benefit of present and future generations."

There is no doubt that for MAP to achieve its vision, it will have to regularly monitor the state of the Mediterranean, and then implement relevant policies based on the findings of the environmental assessments. Environmental data and trends thus function as a feedback mechanism to provide information on the effectiveness of action taken to address a particular issue [e.g. 39, 41, 164]. The Scientific Committee of ACCOBAMS (Agreement on the Conservation of Cetaceans in the Black Sea, Mediterranean Sea and Contiguous Atlantic Area) highlighted the "fundamental need" of having a monitoring program and obtaining baseline population estimates and distributional information of cetaceans in order to analyze the effectiveness of ACCOBAMS conservation efforts [165 p. 308]. At the fifth meeting of the CBD COP, participants noted that an evaluation of the effectiveness of the Cartagena Protocol carried out in 2008 could not provide useful information on the effectiveness of the Protocol due to the absence of a methodological approach. Most significantly, participants recommended that consideration be given to biodiversity indicators being developed in the context of the CBD [56]. A UNEP report on marine litter [166 p. 19] ascribes failure to address the problem of marine litter to lack of monitoring and assessment programs at national, regional and global scales.

In cognizance of this need for environmental data, many IEAs legally mandate regular scientific monitoring and assessments of environmental conditions, as well as scientific and technical cooperation (e.g. IEAs forming part of the Regional Seas Programme; the Convention for the Protection of the Marine Environment of the North-East Atlantic (Paris, 1992)). Often, the mandate for regular environmental monitoring and assessment is assigned to commissions specifically set up for that purpose - e.g. the OSPAR Commission, ${ }^{4}$ HELCOM, the Inter-American Tropical Tuna Commission (IATTC) and the North Atlantic Salmon Conservation Organization (NASCO). The COP of the Ramsar Convention underscores the significance of environmental monitoring in the following words [167]:

"The most prominent and well-known question remains: how can we ensure that the Convention has the necessary understanding of the state of the global wetlands, trends and threats in order to support an up-to-date decision context and to fully engage Contracting Parties where actions must be taken to promote timely and relevant application of the Convention's assets/resources?"

Both the Ramsar COP and the Convention's Scientific and Technical Review Panel (STRP) are closely involved in

\footnotetext{
${ }^{4}$ http://www.ospar.org/eng/html/welcome.html
}

evaluating the effectiveness of the Ramsar Convention through different types of environmental assessments (e.g. baseline inventory, assessing the status, trends, and threats to wetlands, inter alia) [168, 169]. In fact, eight "ecological outcome-oriented indicators" have been developed for determining the effectiveness of the Ramsar Convention.

Thus, if we take into account the management concerns of the IEA institutions, it is clear that there is commitment to developing environmental indicators and evaluating the environmental impact of IEAs. In fact, lots of resources and time are invested in attempts at evaluating the environmental effectiveness of the IEAs. Some COPs have prepared manuals on methodologies and criteria for environmental monitoring [168, 170]. However, it is also true that the IEA institutions do adopt a broad perspective on the indicators of effectiveness, utilizing both quantitative and qualitative data. IEA institutions often embrace a multi-track perspective on effectiveness, analyzing participation growth, successful negotiation and adoption of protocols, establishment of joint research programs, successful establishment of MoUs with other important stakeholders, public awareness projects, as well as the establishment of baseline data and regular environmental monitoring as signs of effectiveness [e.g. 48]. Thus, from a practical viewpoint, different effectiveness indicators can be used at different stages of the life-cycle of an IEA, with varying significance in informing the success of the IEAs in achieving their goals. Indeed, the evolutionary perspective on IEA effectiveness best fits the operation and management of IEAs, and the various potential methodologies can be positioned along a hierarchy based on the criterion of relevance to the ultimate goal of global environmental sustainability. This hierarchy of methodologies is discussed below.

\section{Establishing a Hierarchy of Assessment Methodologies}

In attempting to evaluate the effectiveness of any IEA, the following four core questions need to be answered: (i) What is the purpose of the evaluation? (ii) What resources are available for the evaluation? (iii) What is the typology of the IEA? and (iv) What key data are needed for the effectiveness analysis? All evaluation studies are normally undertaken with a specific purpose as well as a specific audience in mind [156 p. 2]. In normal settings of public policy-making and program evaluation, this sense of purpose is made explicit, and often relates to administrative considerations, efficiency concerns, accountability issues, or impact studies, inter alia [see 171 p. 34, 172 p. 4-12]. Accordingly, effectiveness indicators can pertain to process, impact or efficiency measures [172 p. 5], depending on the nature and purpose of the evaluation exercise.

In the case of IEAs, the purpose of the effectiveness evaluation exercise can include, inter alia, a determination of the success of the IEA in securing commitment from nation states, the successful establishment of IEA-mandated 
institutions, party members' success in implementing specific clauses of the IEAs, and the determination of the environmental impacts of the IEAs. The exact nature of these evaluations and the specific indicators that can be used will vary, depending on the resources available for the evaluations, the typology of the IEAs, as well as the life-span of the IEAs. Resource availability (in terms of time, finance, expertise, technology, etc.) is crucial and often a limiting factor in determining the assessment methodology or the scope of the study [173].

The life-span of an IEA will also be important in determining the indicators that can be used for the determination of the effectiveness of the IEA - either in terms of methodology or of the effectiveness indicators that can be used. In the case of a newly negotiated IEA, the short lifetime precludes full-fledged institutional analysis or elaborate trend analysis of environmental data. In this scenario, interim effectiveness indicators can be used to provide temporary benchmarks for the early success of implementation measures. Thus, in the short time frame (e.g. 0-5 years after entry into force of the IEA), IEA institutions may simply be interested in the answers to the following questions: Is membership growing at a satisfactory level? Are member parties establishing the basic administrative, legislative and technical framework for treaty implementation? Are party members meeting their reporting obligations? Are appropriate funds being secured for the setting up of Secretariats or other bodies (e.g. standing or $\mathrm{ad}$ hoc committees, etc.)? Are mechanisms being put in place for facilitating financial or technological transfers? Are strategies being developed for the establishment of baseline environmental data (especially where such is non-existent)? Answering these questions can provide useful information on how the IEA is thriving in its early phases (see Table 2).

If enough time has elapsed to allow for successful time-series analyses of relevant environmental parameters, the environmental state can be assessed and monitored to determine whether the implementation of the IEA has indeed resulted in the desired environmental changes. For successful implementation of this analytical framework, however, IEAs will need to have a list of potential environmental indicators associated with them and then establish baseline trends on these environmental indicators. Since not all IEAs have the same goals or requirements, not all IEAs will be benefited by one and the same effectiveness assessment methodology or the same type of environmental indicators. It is obvious that the environmental effectiveness indicators for an IEA which deals with the protection of a specific natural habitat (e.g. wetlands) will be different from one which deals with the protection of the marine environment or with acid rain, for example. Potential environmental effectiveness indicators for various types of IEAs are listed in Table 2.

Depending on the resources available, IEA institutions may have to prioritize the indicators - either in terms of ease of measurement, data availability, time constraints, or their relevance to the ultimate environmental goals. However, it is also true that there will be areas of overlap among the various IEAs as many of the environmental problems are interlinked, and it may be more informative to use a mix of indicators. In their study of the possibility of using the extent of protected areas as an indicator of effectiveness for determining biodiversity goals, Chape et al [174] note that measurements of the extent of protected areas must be combined with measures of conservation effectiveness as well to be really meaningful. With the evolutionary understanding of effectiveness, a combination of methodologies may be most useful rather than focusing on the methodologies as mutually exclusive contending or alternative approaches [see for example 48]. The usefulness of environmental indicators has been summarized by Niemeijer and de Groot [175], who also propose a causal network for the selection of environmental indicators. The causal network has the benefits of considering the various interrelationships that exist among indicators, thus providing a more meaningful analysis of the state of the environment.

Table 2. An example of potential indicators of effectiveness for different IEA typologies (a non-exhaustive list of potential environmental indicators based on the textual analysis of IEAs).

\begin{tabular}{|c|c|}
\hline IEA Typ & Potential Indicators of Effectiveness \\
\hline $\begin{array}{l}\text { Early years of } \\
\text { operation } \\
\text { (0-5 years) } \\
\text { [Interim } \\
\text { Effectiveness } \\
\text { Indicators] }\end{array}$ & 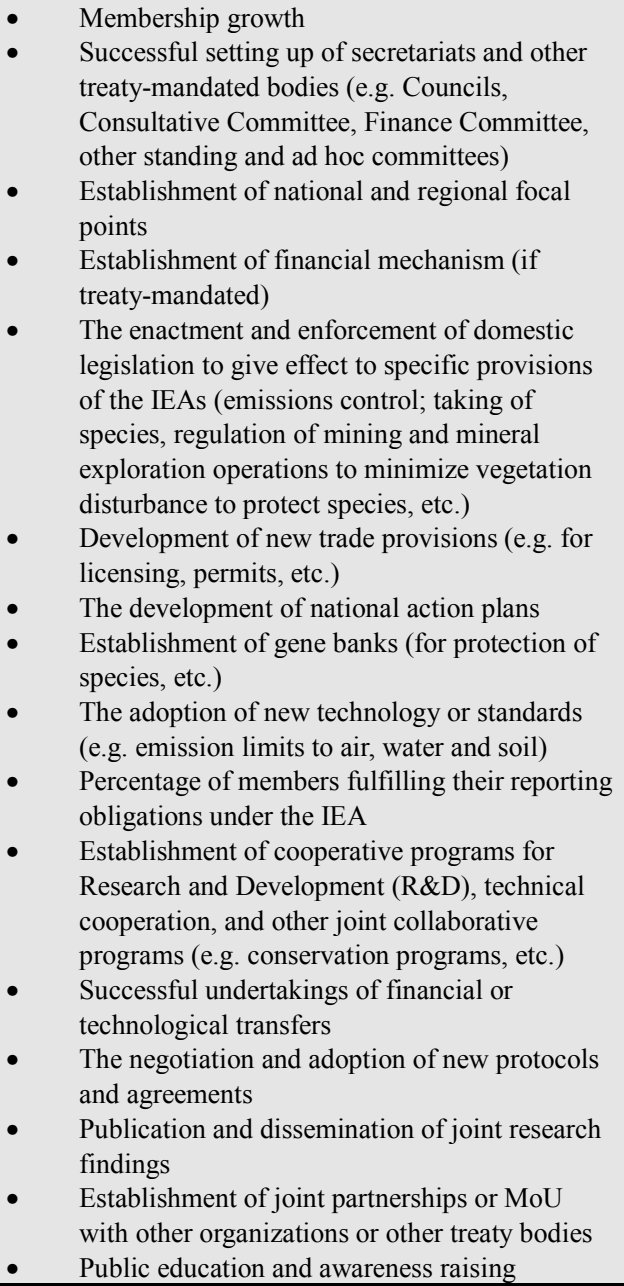 \\
\hline
\end{tabular}




\section{IEA Typology Potential Indicators of Effectiveness}

initiatives (e.g. publications issued and distributed; press releases; website development; media production)

- $\quad$ Training programs for key stakeholders

- Development of forestry management plans in line with ecological principles to maintain resource capital

- Development of agricultural schemes to protect critical habitats and endangered species or the granting of special protection to identified species (See for example, Articles 3, 4,5,6,10 of ASEAN Agreement On The Conservation Of Nature And Natural Resources, Kuala Lumpur, 9 July 1985)

- Successful compilation of baseline information on relevant environmental parameters (e.g. analysis of the hydrographic, meteorological, geological and topographic characteristics of the relevant area, and a determination of the waste receiving capacity of the environmental medium, etc) (See Annex 1 of the Protocol For The Protection Of The South-East Pacific Against Pollution From Land-Based Sources, Quito, 23 July 1983)

- $\quad$ Reporting of data [e.g. 176]

- Pollution prevention projects (especially for wastes reduction)

- $\quad$ Certification schemes and eco-labeling [e.g. 177]

- $\quad$ Preparation of Manuals or Guidelines for the implementation of the IEAs (e.g. reporting of national data, baseline monitoring, etc.) [176]

- The international harmonization of methods

Long-term monitoring of relevant environmental parameters

- The establishment of protected areas (e.g. number of parks, nature reserves, forest reserves, etc. established or acreage of land placed under protective status) - e.g. indicators developed by HELCOM CORESET project [178]

- The development of ecosystem-based indicators (in case these did not exist before)

- Establishment of baseline environmental data (including full integration of existing datasets

Protection of natural habitats and knowledge)
- $\quad$ Environmental monitoring and assessments of the identified environmental indicators

- $\quad$ Status and trends in the ecosystems

- Trends in the ecological character of ecosystems

- Trends in water quality (e.g. level of nitrate, trends in Biological Oxygen Demand (BOD); use of biotic indices)

- $\quad$ Species distribution, population size, habitat level, ecosystem level [178]

- Trends in population of species living in the habitats (e.g. waterbird population for wetlands; wetland-dependent amphibians) [169]

\section{IEA Typology Potential Indicators of Effectiveness}

Protection of

the marine

environment $t^{5}$

Protection of

fisheries

Protection of

fisheries and

marine

resources

(e.g. the

IATTC;

NASCO)

IEAs

controlling

hazardous

substances

Protection of the atmosphere
- Concentrations of organohalogen compounds; organophosphorous compounds; organotin compounds; organosilicon compounds

- Concentrations of the following elements and their compounds: mercury; cadmium; zinc; copper; nickel; chromium; lead; selenium; arsenic; antimony; molybdenum; titanium; tin; barium; beryllium; boron; uranium; vanadium; cobalt; thallium; tellurium; silver

- Concentrations of used lubricating oils; crude oils; hydrocarbons; radioactive substances; cyanides; fluorides; non-biodegradable detergents

- $\quad$ Phosphorus and inorganic compounds of phosphorous

- $\quad$ Presence of pathogenic micro-organisms

- Volume of thermal discharges

- $\quad$ BOD; chemical oxygen demand (COD)

- Concentrations of acid or alkaline compounds

- Volume of wastes discharged

- Number of oil spills; volume of oil discharged

- Volume of $\mathrm{NOx}, \mathrm{SOx}$ and $\mathrm{CO}_{2}$ released from ships

- $\quad$ Stock assessment ${ }^{6}$

- $\quad$ Catch statistics

- Trend in abundance or diversity of population

- Trends in quantity and quality of habitat [e.g. 180]

- Water quality (e.g. sedimentation, siltation, access to spawning habitat and production areas; vegetation cover; water temperature; eutrophication) [180]

- Use of biotic indices to assess water quality

- $\mathrm{pH}$, flow, color, turbidity, presence of heavy metals

- $\quad$ Phosphorous, nitrogen, BOD, COD

- $\quad$ nutrients (e.g. phosphorus, nitrate, nitrite, total nitrogen), metals (e.g., zinc, copper, lead), physical

- $\quad$ parameters (e.g., pH, turbidity) and two to four regionally specific parameters (e.g., chloride, ammonia, dissolved oxygen, pesticides [e.g. 181]

- Volumes of wastes generated

- Import and export of wastes

- Emissions of non-methane volatile organic compounds (NMVOCs)

- Emissions of sulfur, nitrogen oxides, ammonia and volatile organic compounds by sources (e.g. road vehicles, rail transport, ships, aircraft, etc.)

- Depositions and concentrations of the relevant pollutants

- $\quad$ Levels of tropospheric ozone

${ }^{5}$ See the ecological objectives, operational objectives and indicators agreed at the $17^{\text {th }}$ COP Meeting of UNEP/MAP 179. UNEP/MAP State of the Mediterranean Marine and Coastal Environment. 2012: Highlights for Policy-Makers. http://www.grida.no/publications/soemediterranean/; 2012.

${ }^{6}$ IATTC Research http://www.iattc.org/ResearchENG.htm

${ }^{7}$ Protocol To The 1979 Convention On Long-Range Transboundary Air Pollution To Abate Acidification, Eutrophication And Ground-Level Ozone http://www.unece.org/env/lrtap/multi h1.html 


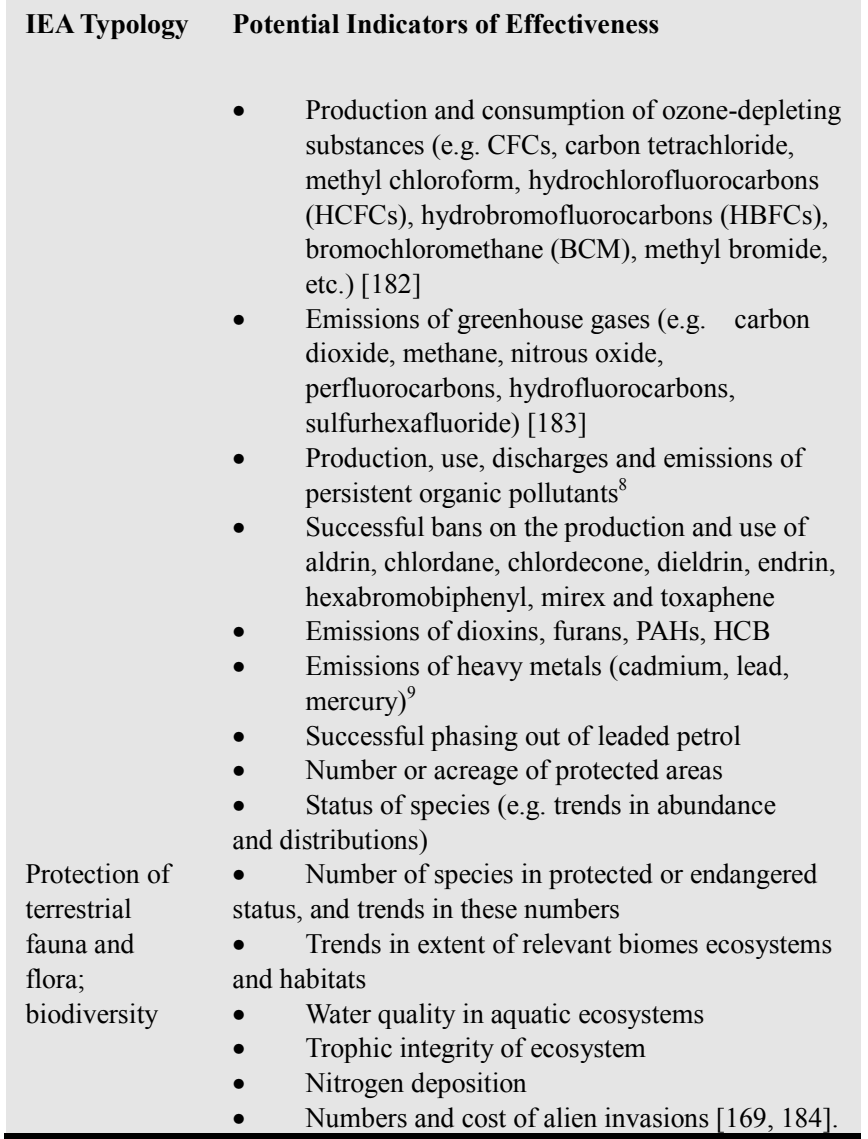

Overall, therefore, we find that depending on the resources and time available, as well as on the purposes of the evaluations, various methodologies may be undertaken to gauge the effectiveness of IEAs. If our ultimate goal is to secure global environmental sustainability, the core premise of this article, we find that an analysis of participation proves to be the least informative (though still relevant). Despite the fact that participation analysis can provide useful information on the level and characteristics of international environmental commitment, it does not necessarily imply compliance and meaningful implementation of the IEA provisions. Thus, participation does not provide a direct means of effectiveness assessment of the IEA per se. Analysis of efforts done at the domestic level (e.g. enactment of legislation, adoption of new environmental standards, setting up of new institutions, fulfilling reporting obligations, etc.) will provide a better understanding of the effectiveness of the IEAs than mere participation. Along the same line, an understanding of the environmental impacts of the IEAs is the most enlightening for our overall criterion of global environmental sustainability. As discussed earlier, for many of the policy goals of environmental management, having key environmental data is a sine qua non.

Thus, analysis of IEA effectiveness has to be undertaken

\footnotetext{
${ }^{8}$ e.g. The 1998 Aarhus Protocol on Persistent Organic Pollutants (POPs)

9 e.g. The 1998 Aarhus Protocol on Heavy Metals
}

vis-à-vis the stated objectives and vision. We can establish a hierarchy of IEA effectiveness methodologies - depending on the power of each assessment methodology in informing us about the success of the IEAs in promoting global environmental sustainability, with participation being the least informative, and environmental monitoring the most informative. Since IEAs are geared towards impacting the environmental medium, we therefore have to assess the state of the environment to determine whether the IEAs have eventually been successful. The best methodology is therefore one which is based on an assessment of the state of the environment and the establishment of trends in relevant environmental parameters [e.g. 179].

It is telling that neither the IEA institutions nor the various IEA objectives or vision statements are couched in language relating to merely effecting changes in the behavior of actors - but always in terms of improving specific components of the environment. In terms of global environmental governance, Dellas et al [185 pp. 89-90] have noted how agency "may be considered exclusively as contributing to problem-solving" and how agents, as opposed to actors, have the capacity to "shape broader norms and values relating to earth system governance." It therefore seems that the behavioral perspective may not be sufficient, in and of itself, in informing environmental policies. For behavioral studies to be relevant, they need to go one step further: to link the behavioral change with changes in environmental conditions. It is a fact that the limitations of environment-based analysis are over-emphasized or exaggerated in the literature on IEA effectiveness, whereas the direct policy-irrelevance of behavioral studies is downplayed.

The demonstration of causality remains the formidable challenge of any study on effectiveness evaluation. Rigid empirical work at demonstrating causality from the environmental problem-solving perspective, without a consideration of the other functions and roles of IEAs (e.g. norm creation, education and awareness, peace promotion, etc.), may come up with the disconcerting result that IEAs have not been effective [e.g. 186]. Overriding academic concerns with establishing causality should not detract from attempts at linking IEA operation with the trends in environmental parameters. Empirical rigor in demonstrating causality may run counter to the policy relevance of the findings. In order to really understand the effect of IEAs, their impact at the domestic level will first have to be studied. Starting at the domestic level is key as analysts will best be able to isolate the effects of the IEAs from other domestic measures in the area. These data can thereafter be aggregated at the national, regional and global level - in a bottom-up and lateral consolidation format [173]. Thus, close collaboration with the domestic institutions of party members is crucial for the relevance, reliability and accuracy of the data. In this context, the IEA institutions can play a significant role in compiling relevant national data of direct relevance to the operation of the IEAs into one database (e.g. 
Ramsar Sites Database ${ }^{10}$ ) and then making them available for researchers and analysts. The COPs, by being in close communication with domestic party members, can work with domestic scientists and institutions to determine exact potential causation pathways for the domestic changes which can be directly associated with the operation of the IEAs. Of course, the capabilities of party members to carry out the relevant scientific investigations and/or implement fully the provisions of the IEAs remains a major hurdle of international environmental protection. Ultimately therefore, the effectiveness of IEAs - as well as a determination of IEA effectiveness - rests upon domestic capabilities for environmental protection.

\section{Conclusion}

This article is premised on the claim that if we have as our ultimate purpose the goal of securing global environmental sustainability, then there is need to verify whether IEAs have "in fact significantly improved the ecological situation compared to that before environmental policies were internationally coordinated" [103 p. 17]. As has been shown, a static understanding of IEA effectiveness does not provide a fair evaluation of the success of the IEAs in moving the global community towards global environmental sustainability. An integrated and holistic understanding of effectiveness, as depicted in the effectiveness web, permits us to determine the effectiveness of IEAs at various stages of their life-cycle, with the full understanding that in the long run, we have to move towards determining the impact of the IEAs on the state of the global environment. Moreover, the strata of effectiveness illustrate clearly that if the international community is to really secure an effective IEA, attention has to be given to all the three determining levels of IEA effectiveness - viz. international negotiations, participation in the IEAs, and then domestic implementation. More importantly, for a comprehensive understanding of the effectiveness of IEAs, there need to be the sharing of knowledge across disciplines. The effectiveness web captures saliently the need for "disciplinary trespassing"'[Hirschman, quoted from 187 p. 4] or "disciplinary interpenetration" [188 p. 193], and shows clearly that IEAs can be evaluated in various ways, and that each methodology contributes to our understanding of IEA effectiveness.

It is important to tailor the effectiveness indicators to what the specific IEA regulates and manages. A multi-track assessment methodology, with a hierarchy of methodologies based on the goal of ensuring sustainability, seems to be more in line with the practical aspects of IEA operation and management. While institutional effectiveness or compliance analyses may help us understand the mechanisms or pathways for IEA effectiveness, the ultimate

\footnotetext{
10

Available at http://ramsar.wetlands.org/Database/SearchforRamsarsites/tabid/765/Default.as $\mathrm{px}$
}

criterion which can direct future environmental goals and objectives rests upon the extent of change brought about in the state of the environment. In discussing the case of the Environmental Protection Agency (EPA) and its use of administrative effectiveness surrogates such as numbers of permits, grants or enforcement actions, Bauer [26 p. 176] notes:

"Given the huge societal costs of both under- and over-regulation, it is incumbent on environmental managers to ensure that their decisions are based, to the extent possible, on the actual environmental data and not on these administrative surrogates."

It is also important to understand the cost implications of not analyzing IEA effectiveness from the problem-solving perspective - viz. the costs of policy-making in absence of real evidence of the impact of the policies at the level where it matters most - the environment. With the present impetus for more integration and synergies among IEAs [173], more environmental data will be needed to judge the effectiveness of the systems put in place. However, success of the environmental modification perspective relies on the availability and accessibility of reliable and comparable environmental data worldwide, and the challenges on this count are many [173].

More importantly, a determination of which assessment methodology to adopt has to consider the needs of the IEA institutions - a major stakeholder that has been too long overlooked in the effectiveness analyses. As the main party responsible for managing the IEAs, it is intriguing that their conceptualizations of effectiveness have been overlooked, and recommendations for effectiveness analysis are made without fitting the technique to the needs and future goals of the IEA institutions. The behavioral intellectual capture of the concept of IEA effectiveness precludes the consideration of the environmental perspective, and the absence of such studies becomes a harbinger of their "lack of worth," preventing more resources from being devoted to their study, thus perpetuating the "vicious cycle of research" expounded by Rogers in regard to the study of organizations [189 p. 24].

We can however end on a hopeful note. The Future We Want lays emphasis on promoting the science-policy interface "through inclusive, evidence-based and transparent scientific assessments, as well as access to reliable, relevant and timely data in areas related to the three dimensions of sustainable development" (par. $76(\mathrm{~g})) .{ }^{11}$ We can therefore expect that in the future, greater emphasis will be placed on linking IEA operation with environmental trends.

\section{References}

[1] GAO International environmental agreements are not well monitored : report to congressional requesters; GAO: Washington, D.C., 1992.

\footnotetext{
${ }^{11}$ www.un.org/futurewewant
} 
[2] Sand, P. H., Lessons Learned in Global Governance. In Environmental Protection and International Law, Lang, W., Neuhold H., and Zemanek K., Ed. Graham \& Trotman: Boston, 1992.

[3] Mitchell, R. B., Intentional Oil Pollution at Sea: Environmental Policy and Treaty Compliance. The MIT Press: Cambridge, Massachusetts, 1994.

[4] Churchill, R., The Contribution of Existing Agreements for the Conservation of Terrestrial Species and Habitats to the Maintenance of Biodiversity. In International Law and the Conservation of Biological Diversity, Bowman, M.; Redgwell, C., Eds. Kluwer Law International: Boston, 1996; Chapter 4.

[5] Chayes, A.; Chayes, A. H., On Compliance. International Organization 1993, 47, (2), 175-205.

[6] Young, O. R., The Effectiveness of International Environmental Regimes : Causal Connections and Behavioral Mechanisms. MIT Press: Cambridge, Mass., 1999; p xiv, 326.

[7] Greene, O., Environmental Regimes: Effectiveness and Implementation Review. In The Environment and International Relations, Vogler, J.; Imber, M. F., Eds. Routledge: New York, 1996; pp 196-214.

[8] Wettestad, J., Designing Effective Environmental Regimes: The Conditional Keys. Global Governance 2001, 7, (3), 317-341.

[9] Helm, C.; Sprinz, D., Measuring the Effectiveness of International Environmental Regimes. The Journal of Conflict Resolution 2000, 44, (5), 630-652.

[10] Mitchell, R. B., Problem Structure, Institutional Design, and the Relative Effectiveness of International Environmental Agreements. Global Environmental Politics 2006, 6, (3), $72-89$.

[11] Böhmelt, T.; Pilster, U. H., International Environmental Regimes: Legalisation, Flexibility and Effectiveness. Australian Journal of Political Science 2010, 45, (2), 245-260.

[12] Frantzi, S.; Carter, N. T.; Lovett, J. C., Exploring discourses on international environmental regime effectiveness with $\mathrm{Q}$ methodology: a case study of the Mediterranean Action Plan. . Journal of Environmental Management 2009, 90, (1), 177-186.

[13] Breitmeier, H.; Underdal, A.; Young, O. R., The Effectiveness of International Environmental Regimes: Comparing and Contrasting Findings from Quantitative Research1. International Studies Review 2011, 13, (4), 579-605.

[14] Hovi, J.; Sprinz, D. F.; Underdal, A., The Oslo-Postdam Solution to Measuring Regime Effectiveness: Critique, Response, and the Road Ahead. Global Environmental Politics 2003, 3, (3), 74-96.

[15] Breitmeier, H.; Underdal, A.; Young, O. R., The Effectiveness of International Environmental Regimes: Comparing and Contrasting Findings from Quantitative Research. International Studies Review 2011, 13, (4), 579-605.

[16] Andresen, S.; Ostreng, W., International Resource Management: The Role of Science and Politics. Belhaven
Press: London, 1989.

[17] Levy, M. A.; Keohane, R. O.; Haas, P. M., Improving the Effectiveness of International Environmental Institutions. In Institutions for the Earth: Sources of Effective Environmental Protection, Haas, P. M.; Keohane, R. O.; Levy, M. A., Eds. MIT Press: Cambridge, 1993; pp. 397-426.

[18] Vogler, J., The Global Commons: A Regime Analysis. John Wiley \& Sons: New York, 1995.

[19] Levy, M. A.; Young, O. R. In The Effectiveness of International Regimes, Annual Convention of International Studies Association, Washington, D.C., 29 March - 1 April 1994, 1994; Washington, D.C., 1994.

[20] Young, O. R.; Levy, M. A., The Effectiveness of International Environmental Regimes. In The Effectiveness of International Environmental Regimes: Causal Connections and Behavioral Mechanisms, Young, O. R., Ed. The MIT Press: Cambridge, Massachusetts, 1999; pp. 1-32.

[21] Sprinz, D.; Vaahtoranta, T., The interest-based explanation of international environmental policy. International Organization 1994, 48, (1), 77-105.

[22] Young, O. R., Rights, Rules, and Resources in World Affairs. In Global Governance: Drawing Insights from the Environmental Experience, Young, O. R., Ed. The MIT Press: Cambridge, Massachusetts, 1997; pp. 1-23.

[23] Underdal, A., One Question, Two Answers. In Environmental Regime Effectiveness: Confronting Theory with Evidence, Miles, E. L.; Underdal, A.; Andresen, S.; Wettestad, J.; Skjaerseth, J. B.; Carlin, E. M., Eds. MIT Press: Cambridge, Massachusetts, 2002; pp. 3-45.

[24] DeSombre, E. R., Domestic Sources of International Environmental Policy: Industry, Environmentalists, and US Power. The MIT Press: Cambridge, Massachusetts, 2000.

[25] Young, O. R., Hitting The Mark: Why Are Some International Environmental Agreements More Successful Than Others? Environment 1999, 41, (8), 20-29.

[26] Bauer, R. R., The United States Approach to Water Pollution Control. In Environmental Law and Policy in the European Union and the United States, Baker, R., Ed. Praeger: Westport, Connecticut, 1997; pp. 169-179.

[27] Heyes, A. G., Making Things Stick: Enforcement and Compliance. In Environmental Policy: Objectives, Instruments, and Implementation, Helm, D., Ed. Oxford University Press Inc.: New York, 2000; pp. 91-110.

[28] Skjaerseth, J. B.; Wettestad, J., Understanding the Effectiveness of EU Environmental Policy: How Can Regime Analysis Contribute? Environmental Politics 2002, 11, (3), 99.

[29] Cendrero, A.; Francés, E.; Corral, D. D.; Fermán, J. L.; Fischer, D.; Río, L. D.; Camino, M.; López, A., Indicators and Indices of Environmental Quality for Sustainability Assessment in Coastal Areas; Application to Case Studies in Europe and the Americas. Journal of Coastal Research 2003, 19, (4), 919-933.

[30] Drapeau, P.; Leduc, A.; Giroux, J.-F.; Savard, J.-P. L.; Bergeron, Y.; Vickery, W. L., Landscape-Scale Disturbances and Changes in Bird Communities of Boreal Mixed-Wood Forests. Ecological Monographs 2000, 70, (3), 423-444. 
[31] Assmann, S. M., Natural Variation in Abiotic Stress and Climate Change Responses in Arabidopsis: Implications for Twenty-First-Century Agriculture. International Journal of Plant Sciences 2013, 174, (1), 3-26.

[32] Silva, D. E.; Badeau, V.; Legay, M.; Corcket, E.; Dupouey, J.-L., Tracking human impact on current tree species distribution using plant communities. Journal of Vegetation Science 2012, 23, (2), 313-324.

[33] Edwards, M.; Johns, D. G.; Leterme, S. C.; Svendsen, E.; Richardson, A. J., Regional Climate Change and Harmful Algal Blooms in the Northeast Atlantic. Limnology and Oceanography 2006, 51, (2), 820-829.

[34] Bignert , A.; Cossa, D.; Emmerson, R.; Fryer, R.; Füll, C.; Fumega, J.; Laane, R.; Calls, H. M.; McHugh, B.; Miller, B.; Millward, G.; Roose, P.; Ruus, A.; Schmolke, S.; Smedes, F.; Strand, J.; Stronkhorst, J.; Thain, J.; Tissier, C.; Tronczynski, J., Final Report. In OSPAR/ICES Workshop on the Evaluation and Update of Background Reference Concentrations (BRCs) and Ecotoxilogical Assessment Criteria (EACs) and how these Assessment Tools Should Be Used in Assessing Contaminants in Water, Sediment and Biota. Traas, T.; Pijnenburg, J.; Moffat, C., Eds. The Hague, Netherlands, 2004, February 9-14.

[35] Reijnders, P. J. H.; Brasseur, S. M. J. M.; Borchardt, T.; Camphuysen, K.; Czeck, R.; Gilles, A.; Jensen, L. F.; Leopold, M.; Lucke, K.; Ramdohr, S.; Scheidat, M.; Siebert, U.; Teilmann, J. Wadden Sea Ecosystem No. 25. Quality Status Report 2009. Thematic Report No. 20. Marine Mammals. Considered during the Tenth Meeting of the Conference of the Parties, Bergen, 20-25 November 2011. Common Wadden Sea Secretariat, Trilateral Monitoring and Assessment Group. UNEP/CMS/Inf.10.18.7.; 2009.

[36] IPCC Contribution of Working Group I to the Fourth Assessment Report of the Intergovernmental Panel on Climate Change; 2007.

[37] Ramsar Secretariat Guidelines for the rapid assessment of inland, coastal and marine wetland biodiversity (Resolution IX.1 Annex $\quad$ E www.ramsar.org/pdf/key_guide_rapidassessment_e.pdf

[38] Bauer, M.; Hoagland, P.; Leschine, T. M.; Blount, B. G.; Pomeroy, C. M.; Lampl, L. L.; Scherer, C. W.; Ayres, D. L.; Tester, P. A.; Sengco, M. R.; Sellner, K. G.; Schumacker, J., The importance of human dimensions research in managing harmful algal blooms. Frontiers in Ecology and the Environment 2010, 8, (2), 75-83.

[39] ECE Convention on the Protection and Use of Transboundary Watercourses and International Lakes: Strategies for Monitoring and Assessment of Transboundary Rivers, Lakes and Groundwaters; Water Convention Secretariat, UN/ECE: Geneva, 2006.

[40] UNEP/MAP, UNEP/MAP: State of the Mediterranean Marine and Coastal Environment, UNEP/MAP - Barcelona Convention, Athens, 2012. 2012.

[41] de Mora, S. Report to UNEP: Review of Marine Pollution Monitoring and Assessment in UNEP's Regional Seas Programmes; IAEA - Marine Environment Laboratory: Monaco, 2004.

[42] UNEP/WHO Water Quality Monitoring. A Practical Guide to the Design and Implementation of Freshwater Quality Studies and Monitoring Programmes; E\&FN SPON:
London, UK, 1996.

[43] Bennett, A.; George, A. L., Process Tracing in Case Study Research. In MacArthur Foundation Workshop on Case Study Methods, Belfer Center for Science and International Affairs (BCSIA), Harvard University. October 17-19, 1997. Available at http://users.polisci.wisc.edu/kritzer/teaching/ps816/ProcessT racing.htm, 1997.

[44] Victor, D. G.; Raustiala, K.; Skolnikoff, E. B., The Implementation and Effectiveness of International Environmental Commitments: Theory and Practice. MIT Press: Cambridge, Massachusetts, 1998.

[45] Saez, R., The Case of a Renewable Natural Resource: Timber Extraction and Trade. In The Environment and International Trade Negotiations: Developing Country Stakes, Tussie, D., Ed. St. Martin's Press, Inc: New York, 2000; pp. 13-31.

[46] Young, O. R., Regime Effectiveness: Taking Stock. In The Effectiveness of International Environmental Regimes: Causal Connections and Behavioral Mechanisms, Young, O. R., Ed. The MIT Press: Cambridge, Massachusetts, 1999; pp. 249-287.

[47] Hisschemöller, M.; Gupta, J., Problem-Solving through International Environmental Agreements: The Issue of Regime Effectiveness. International Political Science Review 1999, 20, (2), 151-174.

[48] CBD Secretariat Technical Advice on the Establishment and Management of a National System of Marine and Coastal Protected Areas (CBD Technical Series no. 13); Secretariat of the Convention on Biological Diversity: Montreal, Canada, 2004.

[49] Ramsar Secretariat, Report of the Secretary General on the Implementation of the Convention at the Global Level. Information Document No. 6 to the COP 10 of the Ramsar Convention. Ramsar COP10 DOC. 6. Retrieved from http://www.ramsar.org/cda/en/ramsar-documents-cops-cop1 0-10th-meeting-19357/main/ramsar/1-31-58-127\%5E19357 _4000_0_.2008, 20 August.

[50] Ramsar Secretariat, The Ramsar Strategic Plan 2009-2015. Retrieved

from http://www.ramsar.org/cda/en/ramsar-documents-plans/main /ramsar/1-31-39_4000_0_.2008.

[51] Ramsar Secretariat, The Ramsar Strategic Plan 2003-2008. Retrieved from http://www.ramsar.org/cda/en/ramsar-documents-plans/main /ramsar/1-31-39_4000_0_.n.d.

[52] Ramsar Secretariat, Resolution IX.1 Annex D: Ecological "outcome-oriented" indicators for assessing the implementation effectiveness of the Ramsar Convention. 9th Meeting of the Conference of the Contracting Parties to the Convention on Wetlands (Ramsar, Iran, 1971). Kampala, Uganda, 8-15 November 2005. Retrieved from http://www.ramsar.org/cda/en/ramsar-documents-resol-resol ution-ix-1-annex-d/main/ramsar/1-31-107\%5E23547_4000 0 _. 2005.

[53] Basel Secretariat, Strategic Plan for the Implementation of the Basel Convention. Retrieved from http://www.basel.int/TheConvention/StrategicPlan/Reporton theStrategicPlan/tabid/1554/Default.aspx. 2002. 
[54] Basel Secretariat, Report on the Review of the Implementation of the Current Strategic Plan, Basel Convention (March 2009). Retrieved from http:/www.basel.int/TheConvention/StrategicPlan/Reporton theStrategicPlan/tabid/1554/Default.aspx. 2009, March.

[55] CMS Secretariat, Resolution 5.4. Strategy for the Future Development of the Convention. Adopted by the Conference of the Parties at its Fifth Meeting (Geneva, 10-16 April 1997). Retrieved from http://www.cms.int/bodies/COP/cop5/cop5_documents_over view.htm. . 1997.

[56] CBD Secretariat, MOP 5 Decision BS-V/15 BS-V/15.Assessment and review (Article 35). Fifth meeting of the Conference of the Parties serving as the meeting of the Parties to the Cartagena Protocol on Biosafety (COP-MOP 5). 11 - 15 October 2010 - Nagoya, Aichi Prefecture, Japan. Retrieved from https://www.cbd.int/decision/mop/default.shtml?id=12328

[57] Honkonen, T., The Common but Differentiated Responsibility Principle in Multilateral Environmental Agreements: Regulator and Policy Aspects. Kluwer Law International: The Netherlands, 2009.

[58] Kutting, G., Environment, Society and International Relations: Towards More Effective International Environmental Agreements. Routledge: New York, 2000.

[59] Kaczorowska, A., International Trade Conventions and Their Effectiveness: Present and Future. Kluwer Law International: The Hague, Netherlands, 1995.

[60] Peterson, M. J., International Organizations and the Implementation of Environmental Regimes. In Global Governance: Drawing Insights from the Environmental Experience, Young, O. R., Ed. The MIT Press: Cambridge, Massachusetts, 1997; pp. 115-151.

[61] Bohmelt, T.; Pilster, U. H., International Environmental Regimes: Legalisation, Flexibility and Effectiveness. Australian Journal of Political Science 2010, 45, (2), 245-260.

[62] Dombrowsky, I., Institutional design and regime effectiveness in transboundary river management -- the Elbe water quality regime. Hydrology \& Earth System Sciences 2008, 12, (1), 223-238.

[63] Miles, E. L.; Underdal, A.; Andresen, S.; Wettestad, J.; Skjaerseth, J. B.; Carlin, E. M., Environmental Regime Effectiveness: Confronting Theory with Evidence. The MIT Press: Cambridge, Massachusetts, 2002.

[64] Skjaerseth, J. B., Toward the End of Dumping in the North Sea: The Case of the Oslo Commission. In Environmental Regime Effectiveness: Confronting Theory with Evidence, Miles, E. L.; Underdal, A.; Andresen, S.; Wettestad, J.; Skjaerseth, J. B.; Carlin, E. M., Eds. The MIT Press: Cambridge, Massachusetts, 2002; pp. 65-85.

[65] Seelarbokus, C. B., Effectiveness of Environmental Treaties: Trend Analysis of Treaty-Based Environmental Indicators. Journal of Environmental Assessment Policy and Management 2005, 7, (3), 493-541.

[66] Mitchell, R. B., International Environmental Agreements Database Project (Version 2013.1). Retrieved from http://iea.uoregon.edu/. . 2002-2013.
[67] Young, O. R., Effectiveness of International Environmental Regimes: Existing Knowledge, Cutting-edge Themes, and Research Strategies. Proceedings of the National Academy of Sciences of the United States of America 2011, 108, (50), 19853-19860, doi: 10.1073/pnas.1111690108.

[68] Young, O. R., International Cooperation: Building Regimes for Natural Resources and the Environment. Cornell University Press: Ithaca, 1989.

[69] Morrow, J. D., Modeling the Forms of International Cooperation: Distribution versus Information. International Organization 1994, 48, (3), 387-423.

[70] Benedick, R. E., Protecting the Ozone Layer: New Directions in Diplomacy. In Preserving the Global Environment: The Challenge of Shared Leadership, Mathews, J. T., Ed. W.W. Norton: New York, 1998.

[71] Rowlands, I. H., Explaining National Climate Change Policies. Global Environmental Change 1995, 5, (3), 235-249.

[72] Doos, B. R., Environmental Issues Requiring International Action. In Environmental Protection and International Law, Lang, W.; Neuhold, H.; Zemanek, K., Eds. Graham \& Trotman: Boston, 1991; p Chapter 1.

[73] Porter, G.; Brown, J. W., Global Environmental Politics. First ed.; Westview Press, Inc.: Boulder, Colorado, 1991.

[74] Corrales, M.; Dreyfus, T., Negotiations Over Auto Emissions Standards in the European Economic Community, 1983-1989. In Nine Case Studies in International Environmental Negotiation, Susskind, L. E., Ed. The MIT-Public Disputes Program.: Mass., 1990; pp et. al. 49-74.

[75] Bodea, S., The Convention on Early Notification and on Assistance in the Case of Nuclear Accident 21 July-15 August, 1986, Vienna. In Nine Case Studies in International Environmental Negotiation, Susskind, L. E.; et.al., Eds. The MIT-Harvard Public Disputes Program: Mass., 1990; pp 207-225.

[76] Boehmer-Christiansen, S., The Role of Science in the International Regulation of Pollution. In International Resource Management: The Role of Science and Politics, Andresen, S.; Ostreng, W., Eds. Belhaven Press: London, 1989; p Chapter 8.

[77] Bodansky, D., Prologue to the Climate Change Convention. In Negotiating Climate Change: The Inside Story of the Rio Convention, I.M., M.; Leonard, J. A., Eds. Cambridge University Press: Cambridge, Massachusetts, 1994; p Chapter 2.

[78] Citron, K., Experience of a Negotiator at the Stockholm Conference. In Processes of International Negotiations, Mautner-Markhof, F., Ed. Westview Press: Chapter 7. San Francisco, 1989.

[79] Grunert, H., Negotiations in Our Time. In Processes of International Negotiations, Mautner-Markhof, F., Ed. Westview Press.: Chapter 20. San Francisco, 1989.

[80] Najam, A., International Environmental Negotiation: A Strategy for the South. In Papers on International Environmental Negotiation, Volume III., Susskind, L. E., Ed. Program on Negotiation at Harvard Law School: Cambridge, Mass., 1993; pp. 187-230. 
[81] Borione, D.; Ripert, J., Exercising Common But Differentiated Responsibility. In Negotiating Climate Change: The Inside Story of the Rio Convention, I.M., M.; Leonard, J. A., Eds. Cambridge University Press: Cambridge, Mass., 1994; Chapter 3.

[82] Dasgupta, C., The Climate Change Negotiations. In Negotiating Climate Change: The Inside Story of the Rio Convention, I.M., M.; Leonard, J. A., Eds. Cambridge University Press: Cambridge, Mass., 1994; Chapter 6.

[83] Nayar, J. R.; Ong, D. M., Developing Countries, Development and the Conservation of Biological Diversity. In International Law and the Conservation of Biological Diversity, Bowman, M.; Regdwell, C., Eds. Kluwer Law International: Boston, 1996; Chapter 12.

[84] McMahon, V., Environmental Nongovernmental Organizations at Intergovernmental Negotiations. In Papers on International Environmental Negotiation., Susskind, L. E., Siskind E. and Breslin J.W., Ed. Harvard Law School: Volume III. Program on Negotiation. Massachusetts, 1993; Vol. Volume III, Program on Negotiation, pp. 1-21.

[85] Handl, G., Environmental Security and Global Change: The Challenges to International Law. In Environmental Protection and International Law, Lang, W., Neuhold H., and Zemanek K., Ed. Graham \& Trotman: Boston, 1991.

[86] Lindborg, N., Nongovernmental Organizations: Their Past, Present, and Future Role in International Environmental Negotiations. In International Environmental Treaty Making, Susskind, L. E., Siskind E. and Breslin J.W., Ed. Harvard Law School: Cambridge, Massachusetts, 1992.

[87] Arend, T. E., Ivory, Elephants, or Both: Negotiating the Transfer of the African Elephant to an Appendix II Within CITES. In International Environmental Treaty-Making. Program on Negotiation, Susskind, L. E., Ed. Harvard Law School: Cambridge, MA, 1990.

[88] Benedick, R. E., Ozone Diplomacy: New Directions in Safeguarding the Planet. Harvard University Press: Cambridge, Mass., 1991.

[89] Bramble, B. J.; Porter, G., Non-Governmental Organizations and the Making of US International Environmental Policy. In The International Politics of the Environment, Hurrell, A. Kingsbury, B, Ed. Clarendon Press: Oxford, 1992; pp. 313-353.

[90] Feld, W. J.; Jordan, R. S.; Hurwitz, L., International Organizations: A Comparative Approach. Praeger: Connecticut, 1994.

[91] Rittberger, V., (I)NGOs and Global Governance: Introduction. In The Global Environment In the Twenty-First Century: Prospects for International Cooperation, Chasek, P. S., Ed. UN University Press: New York, 2000; pp. 83-86.

[92] Stairs, K.; Peter Taylor. Non-Governmental Organizations and the Legal Protection of the Oceans: A Case Study. In The International Politics of the Environment, Hurrell, A. and Kingsbury, B. Eds. Clarendon Press: Oxford, 1992; pp. 110-141.

[93] Wapner, P., The Transnational Politics of Environmental NGOs: Governmental, Economic, and Social Activism. In Chasek, P. S., Ed. UN University Press: New York, 2000; pp. 87-108.
[94] Chayes, A.; Chayes, A. H., The new sovereignty : compliance with international regulatory agreements. Harvard University Press: Cambridge, Mass., 1995; p xii, 417.

[95] Young, O. R., The Effectiveness of International Institutions: Hard Cases and Critical Variables. In Governance Without Government: Order and Change in World Politics, Rosenau, J. N.; Ernst-Otto, C., Eds. Cambridge University Press: Cambridge, 1992.

[96] Victor, D. G.; Greene, O.; Lanchbery, J.; di Primio, J. C.; Anna, K. Review Mechanisms in the Effective Implementation of International Environmental Agreements; WP-94-114; IIASA: Laxenburg, Austria, November 1994, 1994; p. 3.

[97] Treves, T.; Pineschi, L.; Tanzi, A.; Pitea, C.; Ragni, C.; Jacur F. R., Non-Compliance Procedures and Mechanisms and the Effectiveness of International Environmental Agreements. Asser Press: The Hague, The Netherlands, 2009.

[98] Cardesa-Salzmann, A., Constitutionalising Secondary Rules in Global Environmental Regimes: Non-Compliance Procedures and the Enforcement of Multilateral Environmental Agreements. Journal of Environmental Law 2012, 24, (1), 103-132.

[99] Congleton, R. D., Political Regimes and Pollution Control. Review of Economics and Statistics 1992, 74, (August), 412-421.

[100] Congleton, R., Governing the Global Environmental Commons: The Political Economy of International Environmental Treaties and Institutions. In International Environmental Economics: A Survey of Issues, Schulze, G. G.; Ursprung, H. W., Eds. Oxford University Press: Oxford, 2001.

[101] Murdoch, J. C.; Sandler, T.; Sargent, K., Voluntary Cutbacks and Pretreaty Behavior: The Helsinki Protocol and Sulfur Emissions. Public Finance Review 1997, 25, (2), 139-62.

[102] Arts, B., The Impact of Environmental NGOs on International Conventions. In Non-State Actors in International Relations, Arts, B., Math Noorman, and Bob Reinalda, Ed. Ashgate: Burlington, USA, 2001; pp. 195-210.

[103] Schmidt, C., Designing International Environmental Agreements: Incentive Compatible Strategies for Cost-effective Cooperation. Edward Elgar: Northampton, MA, 2000.

[104] Carraro, C., International Environmental Agreements on Climate Change. Kluwer Academic Publishers: Dordrecht, The Netherlands, 1999b.

[105] Barrett, S., International Environmental Agreements as Games. In Conflicts and Cooperation in Managing Environmental Resources, Pethig, R., Ed. Springer: Berlin, 1992; pp. 11-36.

[106] Carraro, C., The Structure of International Environmental Agreements. In International Environmental Agreements on Climate Change, Carraro, C., Ed. Kluwer Academic Publishers: Dordrecht, The Netherlands, 1999a; pp. 9-25.

[107]Folmer, H.; De Zeeuw, A., International Environmental Problems and Policy. In Principles of Environmental and Resource Economics: A Guide for Students and Decision-Makers, Second ed.; Folmer, H.; Gabel, L. H., Eds. Edward Elgar: Northampton, MA, 2000; pp. 447-478. 
[108]Barrett, S., Trade Restrictions in International Environmental Agreements. London Business School: London, 1995.

[109] Heister, J.; Mohr, E.; Plesmann, W.; Stahler, F.; Stoll , T.; Wolfrum, R. Economic and Legal Aspects of International Environmental Agreements - The Case of Enforcing and Stabilising an International CO2 Agreement; Kiel Working Paper No. 711; Kiel Institute of World Economics: 1995.

[110] Botteon, M.; Carraro, C., Strategies for environmental negotiations: issue-linkage with heterogeneous countries. In Game Theory and the Environment, Hanley, N.; Folmer, H., Eds. Edward Elgar: Cheltenham, 1998; pp. 181-203.

[111] Carraro, C., International Environmental Agreements: Strategic Policy Issues. Edward Elgar: Cheltenham, 1997.

[112] Carraro, C.; Siniscalco, D., Policy Coordination For Sustainability: Commitments, Transfers, and Linked Negotiations. In The Economics of Sustainable Development, Goldin, I.; Winters, A., Eds. Cambridge University Press: Cambridge, 1995.

[113] Cesar, H.; De Zeeuw, A., Issue Linkage in Global Environmental Problems. In Economic Policy for the Environment and Natural Resources, Xepapadeas, A., Ed. E. Elgar: Cheltenham, 1994.

[114] Katsoulacos, Y., R\&D Spillovers, R\&D Cooperation, Innovation and International Environmental Agreements. In International Environmental Agreements: Strategic Policy Issues, Carraro, C., Ed. E. Elgar: Cheltenham, 1997.

[115] Carraro, C.; Siniscalco, D., R\&D Cooperation and the stability of international environmental agreements. In International Environmental Agreements: Strategic Policy Issues, Carraro, C., Ed. E. Elgar: Cheltenham, 1997.

[116] Atkinson, A., Environment and Development: Concepts and Practices in Transition. Public Administration and Development 1991, II, 401-413. Quoted from Brinkerhoff and Gage, 2002.

[117] Ledec, G., The Political Economy of Tropical Deforestation. In Divesting Nature's Capital: The Political Economy of Environmental Abuse in the Third World, Leonard, J. H., Ed. Holmes and Meier: New York, 1985; pp. 179-226.

[118] Miller, M., Debt and the Environment: Converging Crises. United Nations Publications. Quoted from Brinkerhoff and Gage, 2002: New York, 1991.

[119] Evans, P., Sustainability, Degradation, and Livelihood in Third World Cities: Possibilities for State-society Synergy. In The Global Environment In the Twenty-First Century: Prospects for International Cooperation, Chasek, P. S., Ed. 2000; pp. 42-63.

[120] von Prittwitz, V., The Catastrophe Paradox: Elements of a Theory of Environmental Policy. Leske and Budrich: Opladen, Germany, 1990.

[121] GAO International environment: Strengthening the implementation of environmental agreements; GAO: Washington, D.C., 1992.

[122] Lang, W.; Neuhold, H.; Zemanek, K., Environmental Protection and International Law. Graham \& Trotman: Boston, 1991.
[123] Hurrell, A.; Kingsbury, B., The International Politics of the Environment. Clarendon Press: Oxford, 1992.

[124] Brinkerhoff, D. W.; Cage, J. D., Natural Resources Management Policy in Africa: Implementation Challenges for Public Managers. In Environmental Policy and Developing Nations, Nagel, S. S., Ed. McFarland \& Company, Inc., Publishers: North Carolina, 2002.

[125] Cowhey, P. F., Domestic Institutions and the Credibility of International Commitments: Japan and the United States. International Organization 1993, 47, (2), 299-326.

[126] Nagel, S. S., Environmental Policy and Developing Nations. McFarland \& Company, Inc., Publishers: North Carolina, 2002.

[127] Caldwell, L. K., Beyond Environmental Diplomacy: The Changing Institutional Structure of International Cooperation. In International Environmental Diplomacy, Carroll, J. E., Ed. Cambridge University Press: New York, 1988; pp. 13-28.

[128] Mallya, F.; Talbott, K. Constraints and Opportunities for Building Local Participation in the Uganda Environmental Action Plan; World Resources Institute, Center for International Development and Environment: Washington, DC, 1990.

[129] OKeefe, P.; Kirby, J.; Cherrett, I., Mozambican Environmental Problems: Myths and Realities. Public Administration and Development 1991, 11, 307-324. Quoted from Brinkerhoff and Cage, 2002. p. 103.

[130] UNEP/CMS Review of Article IV: Agreements Concluded or Under Development. Report presented at the Fifth Meeting of the Conference of Parties of the Convention on the Conservation of Migratory Species of Wild Animals; 1997, 24 March.

[131] Susskind, L., Environmental Diplomacy : Negotiating More Effective Global Agreements. Oxford University Press: New York, 1994; p xii, 201.

[132] Hanf, K., Implementing International Environmental Policies. In Prospects For Environmental Change, Blowers, A.; Glasbergen, P., Eds. John Wiley \& Son: New York, 1995 pp. 197-221.

[133] Seelarbokus, C. B. International Environmental Agreements: Factors Influencing Effectiveness and Participation. Unpublished Master's Thesis. Louisiana State University, Baton Rouge, Louisiana, 1998.

[134] Bretschger, L.; Egli, H., Sustainable Growth in Open Economies. In International Environmental Economics: A Survey of the Issues, Schulze, G. G.; Ursprung, H. W., Eds. Oxford University Press: New York, 2001; pp. 183-208.

[135] Harris, P. G., International Equity and Global Environmental Politics: Power and Principles in US Foreign Policy. Ashgate Publishing Limited: Burlington, VT, 2001.

[136] Von Moltke, K., International Commissions and Implementation of International Environmental Law. In International Environmental Diplomacy, Carroll, J. E., Ed. Cambridge University Press: Cambridge, 1988; pp. 87-93.

[137] Birnie, P., The Role of International Law in Solving Certain Environmental Conflicts. In International Environmental Diplomacy, Carroll, J. E., Ed. 1988; pp. 95-121. 
[138] Bjorkbom, L., Resolution of Environmental Problems: The Use of Diplomacy. In Carroll, J. E., Ed. 1988; pp. 123-137.

[139] Homer-Dixon, T., On The Threshold: Environmental Changes as Causes of Acute Conflict. International Security 1991, 16, (1).

[140] Manwaring, M. G., Environmental Security and Global Stability: Problems and Responses. Lexington Books: Lanham, Maryland, 2002.

[141]Barnett, J., The Meaning of Environmental Security: Ecological Politics and Policy in the New Security Era. Zed Books: New York, 2001.

[142] Conca, K.; Dabelko, G. D., Environmental Peacemaking. Woodrow Wilson Center Press and The John Hopkins University Press: Washington, D.C. and Baltimore, 2002.

[143] Schlosberg, D., Environmental Justice and the New Pluralism: The Challenge of Difference for Environmentalism. Oxford University Press: New York, 1999.

[144] Weiss, E. B., Intergenerational Equity: Toward an International Legal Framework. In Global Accord: Environmental Challenges and International Responses, Choucri, N., Ed. The MIT Press: Cambridge, Massachusetts, 1993; pp. 333-353.

[145] Hertel, S., Promises to Keep: Securing Human Rights in a Changing World. United Nations Association of the United States of America: New York, 1994.

[146] Felice, W. F., Taking Suffering Seriously: The Importance of Collective Human Rights. State University of New York Press: Albany, New York, 1996.

[147] Donnelly, J., International Human Rights: A Regime Analysis. International Organization 1986, 40, (3), 599-642.

[148] Stinchcombe, K.; Gibson, R. B., Strategic Environmental Assessment as a Means of Pursuing Sustainability: Ten Advantages and Ten Challenges. Journal of Environmental Assessment Policy and Management 2001, 3, (3), 343-373.

[149] Pearce, D. W.; Barbier, E.; Markandya, A., Sustainable Development, Economics and Environment in the Third World. Edward Elgar.: London, 1990.

[150] Neumayer, E., Weak versus Strong Sustainability: Exploring the Limits of Two Opposing Paradigms. Edward Elgar: Cheltenham, UK, 1999.

[151] Malone, T. C., The Coastal Module of the Global Ocean Observing System (GOOS): An Assessment of Current Capabilities to Detect Change. Marine Policy 2003, 27, 295-302.

[152] OECD. Environmental Indicators: Development, Measurement, and Use; OECD: Paris, 2003.

[153] OECD. Key Environmental Indicators; OECD: Paris, 2008.

[154] OECD. Environmental Indicators for Agriculture: Concepts and Framework; OECD: Paris, 1999.

[155] OECD. Environmental Indicators: Towards Sustainable Development; OECD: Paris, 2001.

[156] Hammond, A.; Adriaanse, A.; Rodenburg, E.; Bryant, D.; Woodward, R. Environmental Indicators: A Systematic
Approach to Measuring and Reporting on Environmental Policy Performance in the Context of Sustainable Development; World Resources Institute: Washington, D.C., 1995.

[157] Pearce, D.; Hamilton, K.; Atkinson, G., Measuring Sustainable Development: Progress on Indicators. Environment and Development Economics, 1, pp. 85-101. doi:10.1017/S1355770X00000395. 1996.

[158] van Heijnsbergen, P., International Legal Protection of Wild Fauna and Flora. IOS Press: Amsterdam, The Netherlands, 1997.

[159] Leadley, P.; Pereira, H. M.; Alkemade, R.; Fernandez-Manjarrés, J. F.; Proença, V.; Scharlemann, J. P. W.; Walpole, M. J. Biodiversity Scenarios: Projections of 21 st Century Change in Biodiversity and Associated Ecosystem Services. Montreal. Technical Series. No. 50; Secretariat of the Convention on Biological Diversity: 2010.

[160] Ervin, D. E., Trade, Agriculture, and Environment. In International Environmental Economics: A Survey of the Issues, Schulze, G. G.; Ursprung, H. W., Eds. Oxford University Press: New York, 2001; pp. 84-113.

[161] HELCOM, Assessing the progress towards reaching HELCOM objectives for a healthy Baltic Sea. Retrieved from

http://www.helcom.fi/BSAP_assessment/en_GB/main/2010, 28 May.

[162] UNEP Ecosystem-based Management of Fisheries: Opportunities and challenges for coordination between marine Regional Fishery Bodies and Regional Seas Conventions. UNEP Regional Seas Reports and Studies No. 175. http://www.unep.org/regionalseas/publications/reports/RSR S/; 2001.

[163] UNEP Achievements and Planned Development of UNEP's Regional Seas Programme and Comparable Programmes Sponsored by Other Bodies. Regional Seas Reports and Studies No. $1 . \quad$ UNEP http://www.unep.org/regionalseas/publications/reports/RSR S/; 1982.

[164] UNEP/MAP, State of the Mediterranean Marine and Coastal Environment. Highlights for Policy-Makers. http://www.unepmap.org/2012.

[165] ACCOBAMS Secretariat, Report of the 2nd Meeting of the Scientific Committee of ACCOBAMS. Recommendation 2.9: The fundamental need for information on abundance and distribution of cetaceans within the area. ANNEX XXXIVi. Retrieved from www.accobams.org/index.php?option=com_docman\&task= doc... 2003, November.

[166] UNEP Marine Litter: A Global Challenge; UNEP: Nairobi, 2009.

[167] Ramsar Secretariat, Ramsar COP 10. Document 6 (page 3). Agenda Item XI. Report of the Secretary General on the Implementation of the Convention at the global level. 10th Meeting of the Conference of the Contracting Parties to the Convention on Wetlands (Ramsar, Iran, 1971). Changwon, Republic of Korea, 28 October - 4 November 2008. http://www.ramsar.org/cda/en/ramsar-documents-cops-cop1 0-10th-meeting-19357/main/ramsar/1-31-58-127\%5E19357 $4000 \quad 0 \quad 2008$, November. 
[168] Bennett, G.; Mulongoy, K. J. Review of Experience with Ecological Networks, Corridors and Buffer Zones. CBD Technical Series No. 23. ; Secretariat of the Convention on Biological Diversity. Retrieved from https://www.cbd.int/doc/publications/cbd-ts-23.pdf: Montreal, Canada. , 2006, March.

[169] Ramsar Secretariat, Resolution IX.1. Annex E. An Integrated Framework for Wetland Inventory, Assessment and Monitoring (IF-WIAM). 9th Meeting of the Conference of the Contracting Parties to the Convention on Wetlands (Ramsar, Iran, 1971). Kampala, Uganda, 8-15 November $2005 . \quad$ Retrieved from http://www.ramsar.org/cda/en/ramsar-documents-resol-resol ution-ix-1-annex-e-23524/main/ramsar/1-31-107\%5E23524 _4000_0_.2005, November.

[170] UNECE, Guidance documents and other methodological materials for the implementation of the 1999 Protocol to Abate Acidification, Eutrophication and Ground-level Ozone (Gothenburg Protocol). Retrieved from http://www.unece.org/environmental-policy/treaties/air-poll ution/guidance-documents-and-other-methodological-materi als/gothenburg-protocol.html. n.d.

[171] Rossi, P. H.; Freeman, H. E., Evaluation: A Systematic Approach. SAGE Publications: California, 1993.

[172] Knaap, G. J.; Tschangho, J. K., Environmental Program Evaluation: Framing the Subject, Identifying Issues. In Environmental Program Evaluation: A Primer, Knaap, G. J.; Tschangho, J. K., Eds. University of Illinois Press: Chicago, 1998; pp. 1-20.

[173] Seelarbokus, C. B., Assessing the Effectiveness of International Environmental Agreements (IEAs): Demystifying the Issue of Data Unavailability. SAGE Open 2014, 4, (1), DOI: $10.1177 / 2158244014521820$.

[174] Chape, S.; Harrison, J.; Spalding, M.; Lysenko, I., Measuring the Extent and Effectiveness of Protected Areas as an Indicator for Meeting Global Biodiversity Targets. Philosophical Transactions: Biological Sciences 2005, 360, (1454), 443-455.

[175] Niemeijer, D.; de Groot, R. S., A conceptual framework for selecting environmental indicator sets. Ecological Indicators 2008, 8, 14-25.

[176] Basel Secretariat, Guidance Document on Improving National Reporting by Parties to the Basel Convention. Committee for administering the Mechanism for promoting implementation and compliance of the Basel Convention. Retrieved from http://www.basel.int/Implementation/LegalMatters/Complia nce/Overview/tabid/2308/Default.aspx2009, September.

[177] Basel Secretariat, Report of the third meeting of the technical expert group to develop a framework for the environmentally sound management of wastes. Technical expert group to develop a framework for the environmentally sound management of wastes. Third meeting. Glion, Switzerland, 21-23 January 2013. UNEP/CHW/CLI/TEG.3/2. Retrieved from http://www.basel.int/Implementation/LegalMatters/Country
LedInitiative/OutcomeofCOP10/DevelopingguidelinesforES M/TechnicalExpertGroup/LatestMeeting/MeetingDocument s/tabid/2975/Default.aspx. 2013.

[178] HELCOM. Development of a Set of Core Indicators: Interim report of the HELCOM CORESET Project. PART A Description of the selection process. Balt. Sea Environ. Proc. No. 129A; 2012.

[179] UNEP/MAP State of the Mediterranean Marine and Coastal Environment. 2012: Highlights for Policy-Makers. http://www.grida.no/publications/soemediterranean/; 2012.

[180] NASCO, Interim Report of the Habitat Protection, Restoration and Enhancement Focus Area Review Group. Retrieved from http://www.nasco.int/implementation_plans.html. 2009, May 11.

[181] Environment Canada, Data Sources and Methods for the Freshwater Quality Indicator. Retrieved from http://www.ec.gc.ca/indicateurs-indicators/default.asp?lang= en\&n=5D193531-1. 2012, April.

[182] Ozone Secretariat, Data Reporting and Access. Retrieved from http://ozone.unep.org/Data_Reporting/. 2004.

[183] UNFCCC, GHG data from UNFCCC. Retrieved from http://unfecc.int/ghg_data/ghg_data_unfecc/items/4146.php. 2013.

[184] CBD Secretariat, Implementation of the Strategic Plan: Evaluation of Progress Towards the 2010 Biodiversity Target: Development of Specific Targets, Indicators and a Reporting Framework. Conference of the Parties to the Convention on Biological Diversity. Seventh meeting. Kuala Lumpur, 9-20 and 27 February 2004. $\mathrm{UNEP} / \mathrm{CBD} / \mathrm{COP} / 7 / 20 /$ Add.3. Retrieved from www.cbd.int/doc/meetings/cop/cop-07/official/cop-07-20-ad d3-en.pdf. 2003, 4 December.

[185] Dellas, E.; Pattberg, P.; Betsill, M., Agency in Earth System Governance: Refining a Research Agenda. International Environmental Agreements 2011, 11, 85-98. DOI 10.1007/s10784-011-9147-9.

[186] Ringquist, E. J.; Kostadinova, T., Assessing the Effectiveness of International Environmental Agreements: The Case of the 1985 Helsinki Protocol. American Journal of Political Science 2005, 49, (1), 86-102.

[187] Cason, J. W.; Ramaswamy, S., An Introduction to the Debates. In Development and Democracy: New Perspectives on an Old Debate, Ramaswamy, S.; Cason, J. W., Eds. University Press of New England: London, 2003.

[188] Rengger, N. J., International Relations, Political Theory and the Problem of Order: Beyond International Relations Theory? Routledge: New York, 2000.

[189] Rogers, P. C., Co-producing Philanthropic Knowledge in African American Communities. In Fundraising in Diverse Cultural and Giving Environments. New Directions for Philanthropic Fundraising. No. 37. Fall 2002. pp. 23-33, Fogal, R., Ed. 2002. 